\title{
T-Cell Signaling Regulated by the Tec Family Kinase, Itk
}

\author{
Amy H. Andreotti ${ }^{1}$, Pamela L. Schwartzberg ${ }^{2}$, Raji E. Joseph ${ }^{1}$, and Leslie J. Berg ${ }^{3}$ \\ ${ }^{1}$ Department of Biochemistry, Biophysics and Molecular Biology, lowa State University, Ames, lowa 50011 \\ ${ }^{2}$ National Human Genome Research Institute, National Institutes of Health, Bethesda, Maryland 20814 \\ ${ }^{3}$ Department of Pathology, University of Massachusetts Medical School, Worcester, Massachusetts 01655 \\ Correspondence: amyand@iastate.edu
}

The Tec family tyrosine kinases regulate lymphocyte development, activation, and differentiation. In T cells, the predominant Tec kinase is Itk, which functions downstream of the T-cell receptor to regulate phospholipase $\mathrm{C}-\boldsymbol{\gamma}$. This review highlights recent advances in our understanding of Itk kinase structure and enzymatic regulation, focusing on Itk protein domain interactions and mechanisms of substrate recognition. We also discuss the role of Itk in the development of conventional versus innate T-cell lineages, including both $\alpha \beta$ and $\gamma \delta$ T-cell subsets. Finally, we describe the complex role of Itk signaling in effector T-cell differentiation and the regulation of cytokine gene expression. Together, these data implicate Itk as an important modulator of T-cell signaling and function.

$T^{\text {hetcing }}$ he Tec family nonreceptor tyrosine kinases, Tec, Btk, Itk/Emt/Tsk, Rlk/Txk, and Bmx/ Etk, are expressed primarily in hematopoietic cells and serve as important mediators of antigen receptor signaling in lymphocytes (Berg et al. 2005; Felices et al. 2007; Readinger et al. 2009). The demonstration that the human B-cell immunodeficiency, X-linked agammaglobulinemia (XLA), is caused by mutations in Btk first underscored the importance of this tyrosine kinase family in lymphocyte development and antigen receptor signaling (Rawlings et al. 1993; Thomas et al. 1993; Tsukada et al. 1993; Vetrie et al. 1993). T lymphocytes express three Tec kinases: Itk, Rlk and Tec. To date, only Itk has been found to have a clearly defined function in $\mathrm{T}$ cells, leading to the conclusion that Itk is the predominant Tec kinase in T cells. In this review, we will cover recent findings that highlight the critical role of Itk in T-cell signaling and function.

\section{STRUCTURE AND REGULATION OF ITK ACTIVITY}

\section{Tec Kinase Domain Structure}

Itk (inducible T-cell kinase; also known as Emt, expressed in mast cells and $\mathrm{T}$ lymphocytes, and Tsk, T-cell-specific kinase) was cloned in the early 1990s (Siliciano et al. 1992; Gibson et al. 1993; Heyeck and Berg 1993; Tanaka et al. 1993; Yamada et al. 1993). The domain organization of Itk and related Tec kinase family

Editors: Lawrence E. Samelson and Andrey Shaw

Additional Perspectives on Immunoreceptor Signaling available at www.cshperspectives.org

Copyright (C) 2010 Cold Spring Harbor Laboratory Press; all rights reserved; doi: 10.1101/cshperspect.a002287

Cite this article as Cold Spring Harb Perspect Biol 2010;2:a002287 
A.H. Andreotti et al.

members shares similarities with other tyrosine kinase families but also reveals unique features (Fig. 1A). Shared features include the common SH3-SH2-kinase cassette also found in the Src, Csk, and Abl kinases (Williams et al. 1998; Tsygankov 2003). Four of the five Tec tyrosine kinases (Itk, Btk, Tec, and Bmx) contain an amino-terminal region that includes a pleckstrin homology $(\mathrm{PH})$ domain, followed by a $\mathrm{Zn}^{++}$binding region termed the Btk homology (BH) motif, and (except for Bmx) a proline rich region $(\mathrm{PRR})$ that conforms to the con- sensus sequence of an SH3 ligand. Instead of the $\mathrm{PH}-\mathrm{BH}$ region, Txk (also known as Rlk) contains a cysteine string motif at its amino terminus.

\section{Itk Activation Downstream of the TCR}

The Tec family kinases are involved in multiple receptor-mediated signaling pathways in many cell types; several recent reviews have covered these in depth (Berg et al. 2005; Felices et al. 2007; Gomez-Rodriguez et al. 2007; Mihara

A

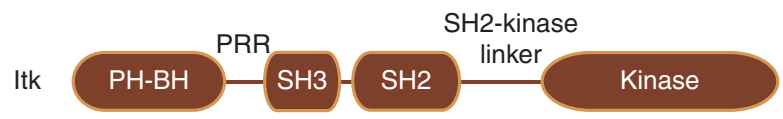

B

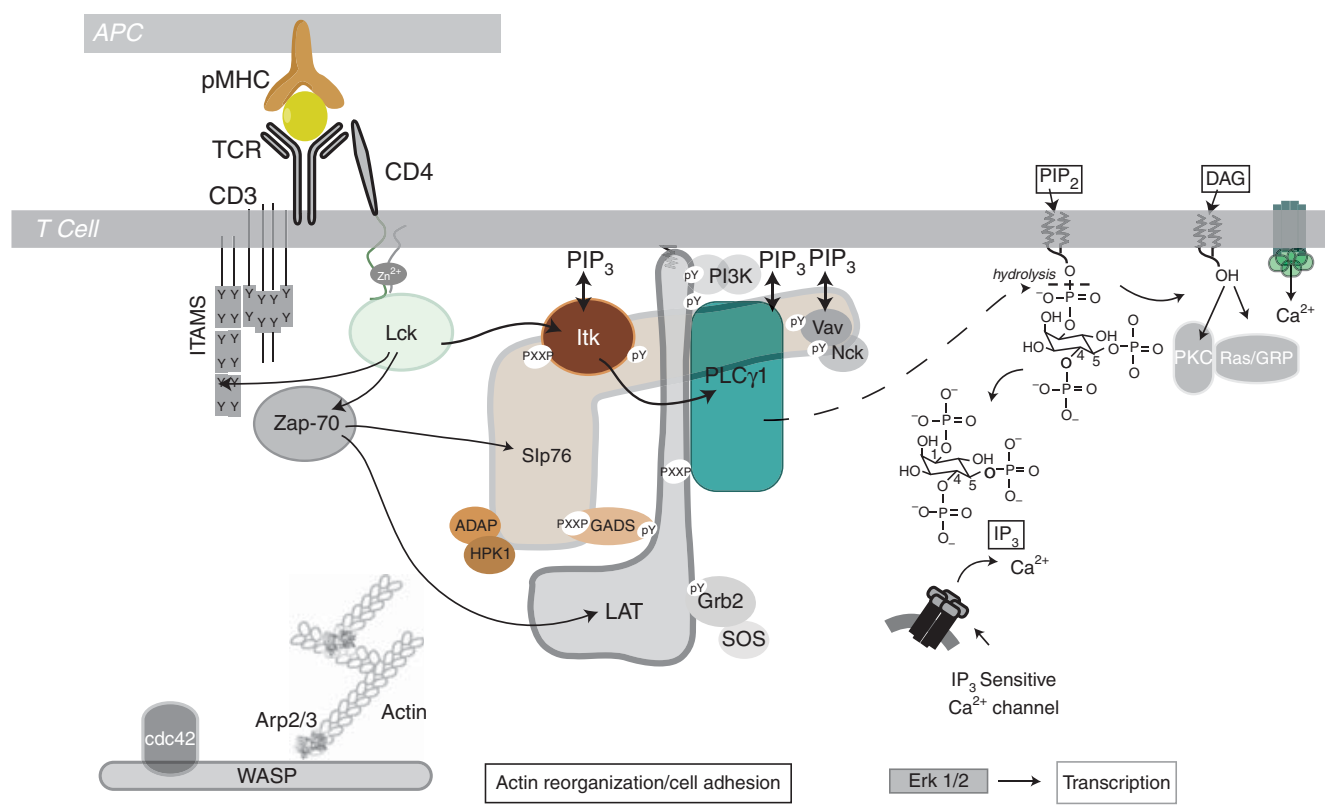

Figure 1. Itk domain organization and it's role in T cell signaling. (A) The domain structure of Itk. (B) Schematic of T-cell signaling emphasizing the proximal signaling complex downstream of the TCR as described in the text. The trio of tyrosine kinases, Zap-70, Lck, and Itk that initiate signaling following TCR engagement are shown as gray, green, and brown circles, respectively. Arrows indicate early phosphorylation events on TCR/ pMHC recognition. The amino-terminal region of Lck binds to the cytoplasmic tail of CD4 via coordination of $\mathrm{Zn}^{++}$(Huse et al. 1998). Active Lck phosphorylates the ITAMs, Zap-70, and Itk, which in turn phosphorylate their targets Slp-76, LAT (by Zap-70) and PLC $\gamma 1$ (by Itk). Activated PLC $\gamma 1$ then hydrolyzes $\mathrm{PIP}_{2}$ (dashed arrow) to produce DAG and $\mathrm{IP}_{3}$ leading to increased calcium flux. Multiple copies of these signaling molecules likely cooperate in the phosphorylation cascade and so stoichiometry as shown is overly simplified. Moreover, negative regulation of the signaling cascade in the form of phosphatases, kinases and other types of molecules also plays a significant role in T-cell function but are not represented here. 
and Suzuki 2007; Gilfillan and Rivera 2009; Koprulu and Ellmeier 2009; Prince et al. 2009; Readinger et al. 2009). For Itk, significant attention has been given to activation via T-cell receptor (TCR) stimulation (see Fig. 1B). Interaction of the TCR with peptide-MHC complexes on antigen presenting cells (APC) activates the Src kinase Lck, leading to phosphorylation of the CD3 immunoreceptor tyrosine-based activation motifs (ITAMs). Zap-70 then binds to the phosphorylated ITAMs and is phosphorylated by Lck, resulting in Zap-70 activation and subsequent phosphorylation of the adaptors LAT and SLP-76 (Pitcher and van Oers 2003; Houtman et al. 2005; Au-Yeung et al. 2009; SmithGarvin et al. 2009). Following activation of PI3K and accumulation of phosphatidylinositol $(3,4,5)$ trisphosphate $\left(\mathrm{PIP}_{3}\right)$ in the plasma membrane, Itk is recruited to the membrane via its $\mathrm{PH}$ domain (August et al. 1997; Ching et al. 1999; Yang et al. 2001). There, Itk interacts with the phosphorylated SLP-76/LAT adapter complex via Itk's Src homology (SH3 and SH2) domains (Bubeck Wardenburg et al. 1996; Zhang et al. 1998; Shan and Wange 1999; Su et al. 1999; Bunnell et al. 2000; Ching et al. 2000; Sommers et al. 2004; Koretzky et al. 2006), permitting phosphorylation of Itk on its activation loop (Y511) by Lck (Heyeck et al. 1997).

Once activated, Itk undergoes cis autophosphorylation on Y180 in its SH3 domain (Wilcox and Berg 2003; Joseph et al. 2007a). Itk also interacts with and directly phosphorylates its downstream target, PLC $\gamma 1$ (Perez-Villar and Kanner 1999; Joseph et al. 2007c), resulting in phospholipase activation (Liu et al. 1998; Schaeffer et al. 1999; Wilcox and Berg 2003; Bogin et al. 2007). The kinetics characterizing many of these early phosphorylation events have been delineated, providing an understanding of the sequential nature of signaling following TCR engagement (Houtman et al. 2005). It is not known, however, whether Itk autophosphorylation occurs prior to, or following, phosphorylation of PLC $\gamma 1$. Because autophosphorylation on Y180 does not affect Itk catalytic activity but instead modulates binding of the Itk SH3 domain to different targets (Wilcox and Berg 2003; Joseph et al. 2007a),
Itk autophosphorylation may serve as a trigger to alter protein interaction partners or localization either before or after PLC $\gamma 1$ activation. PLC $\gamma 1$, once activated, hydrolyzes $\mathrm{PIP}_{2}$ to produce the second messengers $\mathrm{IP}_{3}$ and $\mathrm{DAG}$ (Rhee 2001). Downstream consequences include $\mathrm{Ca}^{2+}$ flux (Lewis and Cahalan 1995), Erk activation (Schaeffer et al. 1999; Schaeffer et al. 2000; Miller and Berg 2002), transcription (Crabtree and Olson 2002), cytokine release (Liao and Littman 1995; Liu et al. 1998), and actin reorganization (Labno et al. 2003), all of which are impaired in the absence of Itk. Importantly, these downstream consequences of TCR activation are not ablated by a deficiency in Itk, but instead, are substantially reduced, leading to altered development and differentiation of distinct T-cell lineages, as discussed later.

\section{The Itk Signaling Complex}

The Itk/SLP-76 interaction likely involves the SH3 and SH2 domains of Itk targeting a proline-rich stretch within SLP-76 (residues 184-195) and an adjacent phosphorylated tyrosine (Y145) in SLP-76, respectively (Su et al. 1999; Bunnell et al. 2000). In an elegant knockin mouse study, tyrosine 145 of SLP-76 was replaced with the nonphosphorylatable phenylalanine to probe the contribution of the ItkSH2/pY145 interaction to signaling (Jordan et al. 2008). Mutation of Y145 resulted in markedly diminished PLC $\gamma 1$ phosphorylation, decreased $\mathrm{Ca}^{2+}$ flux, lowered phospho-ERK levels and gave rise to $\mathrm{T}$ cells that resembled those lacking Itk, as discussed later. This observation (Jordan et al. 2008) is consistent with findings that the Itk/SLP-76 interaction is required to activate Itk kinase activity in Jurkat cells (Bogin et al. 2007). Intriguingly, the majority of the catalytically active Itk in the cell consists of only the small fraction of Itk that is bound to SLP-76 (Bogin et al. 2007). Surprisingly, the SLP-76 Y145F mutation did not lead to loss of the Itk/SLP-76 association (Jordan et al. 2008) despite altered signaling. This finding suggests that cooperative multivalent interactions preserve Itk localization in this signaling complex even when a single contact site is disrupted. 
A.H. Andreotti et al.

The importance of the Itk $\mathrm{PH}$ domain $/ \mathrm{PIP}_{3}$ interaction (Fukuda et al. 1996; August et al. 1997) was also recently probed by inhibition of phosphatidylinositol-3 kinase (PI3K) activity in human peripheral blood T cells (CruzOrcutt and Houtman 2009). In a manner similar to SLP-76 Y145F, loss of the Itk PH domain $/ \mathrm{PIP}_{3}$ interaction resulted in impaired downstream signaling but did not affect the ability of Itk and other PH domain containing signaling proteins to assemble into the signaling complex (Cruz-Orcutt and Houtman 2009). In a separate study, soluble $\mathrm{IP}_{4}$ was found to promote binding of the Itk $\mathrm{PH}$ domain to $\mathrm{PIP}_{3}$ (Huang et al. 2007). Reminiscent of the Itk/SLP-76 interaction (Bogin et al. 2007), these studies also showed that only a limited pool of Itk in the cell is capable of binding $\mathrm{PIP}_{3}$ even in the presence of excess $\mathrm{PIP}_{3}$ (Huang et al. 2007). These separate findings suggest that multiple interaction sites exist to properly localize Itk following TCR stimulation (Graef et al. 1997; Garcon and Nunes 2006; Beach et al. 2007). Furthermore, part of the function of Itk and other proteins in the LAT/SLP-76 complex may be to function as adaptors and stabilize proteins in the complex. Kinase-independent functions for Itk have been observed in the regulation of actin polymerization (Dombroski et al. 2005) and activation of the transcription factor, SRF (Hao et al. 2006); these functions may be secondary to effects on recruitment of the guanine-nucleotide exchange factor Vav to this complex (Labno et al. 2003).

\section{Regulation of Itk Activity}

The regulatory mechanisms that control the activity of Lck and Zap-70 during TCR signaling have been the subject of intense investigation, leading to detailed insights into function (Palacios and Weiss 2004; Au-Yeung et al. 2009). In contrast, a mechanistic understanding of Itk regulation remains elusive, as Itk and other Tec kinases have, to date, resisted crystallization in their full-length form. Comparing the Tec and Src kinase families, it is evident that regulatory differences must exist. In spite of the shared SH3-SH2-Kinase cassette, the
Tec kinases lack the carboxy-terminal regulatory tail that plays an important role in Src regulation (Brown and Cooper 1996; Xu et al. 1997; Xu et al. 1999; Cowan-Jacob et al. 2005). Moreover, removal of the noncatalytic domains from the Src kinase domain yields an active enzyme, whereas the isolated Itk and Btk kinase domains show poor catalytic activity (Fig. 2A) (LaFevre-Bernt et al. 1998; Hawkins and Marcy 2001; Guo et al. 2006; Joseph et al. 2007b). Mutation of a well-conserved tryptophan residue in the Itk and Btk SH2-kinase linkers (W355 in Itk, W395 in Btk) results in a significant decrease in kinase activity (Lin et al. 2005; Guo et al. 2006; Joseph et al. 2007b) whereas mutation of the corresponding tryptophan in the Src kinase Hck leads to a dramatic increase in the activity of that kinase (LaFevre-Bernt et al. 1998). In this regard, Itk is similar to Csk (carboxy-terminal Src kinase), another tyrosine kinase comprised of the common SH3-SH2Kinase cassette and regulated in a manner opposite that of Src (Huang et al. 2009). The isolated Csk kinase domain shows negligible catalytic activity (Fig. 2A) and mutation of the conserved tryptophan (W188) decreases Csk activity (Lin et al. 2005). Based on similar biochemical profiles, a model for active Itk can be developed using the available structure of active Csk (Fig. 2B).

In agreement with the established interaction between active Itk and SLP-76 (Jordan et al. 2008; Bogin et al. 2007), the distance between the $\mathrm{SH} 3$ and $\mathrm{SH} 2$ binding pockets in the high-resolution structure of Csk closely matches the distance between the phosphotyrosine motif and proline-rich region in SLP-76 (residues 143-195). Moreover, the Itk PRR region adjacent to the Itk $\mathrm{SH} 3$ domain in the model of active Itk (Fig. 2B) could be available for binding to an $\mathrm{SH} 3$ domain from an exogenous signaling partner. The precise binding partner of the Itk PRR is not yet clear but candidates include the SH3 domains of Vav, Fyn, Src, PLC 11 or Grb2 (Yang et al. 1995; PerezVillar and Kanner 1999; Bunnell et al. 2000; Chamorro et al. 2001). Csk lacks the PH-BH region of the Tec kinases and so comparative model building for this region of Itk becomes 
Tec Kinase Itk in T-Cell Signaling

A

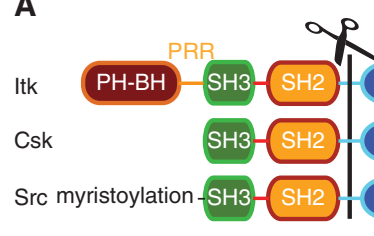

B

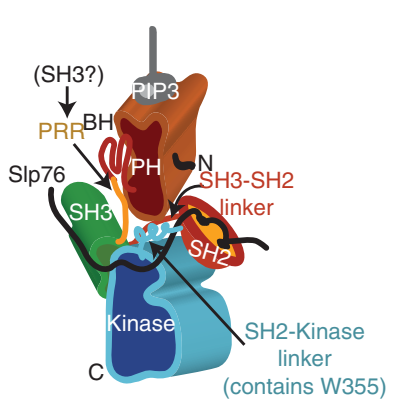

C

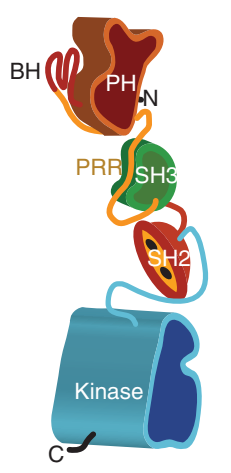

D

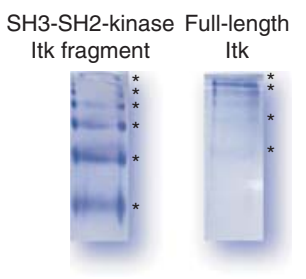

E

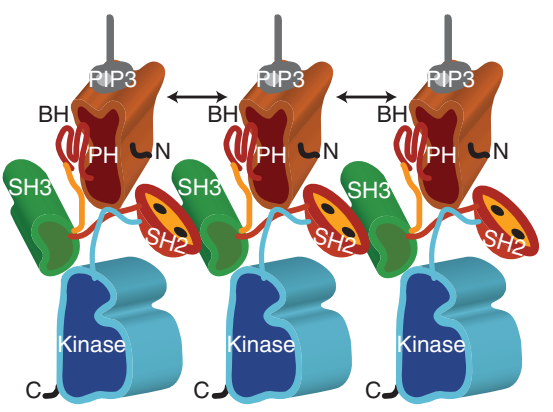

Figure 2. Activation/inactivation of Itk. (A) Comparison of the domain structures of Itk, Csk and Src kinases. The domains are colored as follows: $\mathrm{PH}-\mathrm{BH}$ is brown, $\mathrm{PRR}$ is yellow, $\mathrm{SH} 3$ is green, $\mathrm{SH} 2$ is orange, $\mathrm{SH} 2-\mathrm{Kinase}$ linker and Kinase domain are blue. All three kinases share the SH3-SH2-kinase cassette but differ with respect to resulting catalytic activity of the isolated kinase domain. Itk and Csk kinase domains alone show very poor catalytic activity whereas the Src kinase domain readily phosphorylates substrates. $(B)$ Model of active Itk based on biochemical data and the high-resolution structure of Csk (PDB code: 1K9A). The SH2-Kinase linker and SH3-SH2 linker are both arranged along the back of the small kinase lobe. Activating interactions between the kinase domain and the SH2-kinase linker in particular are also supported by a recent structure of Btk (Marcotte et al. 2010). SLP-76 is depicted by the black line and is shown binding to both Itk SH3 and $\mathrm{SH}$. The $\mathrm{PH}-\mathrm{BH}$ domain is placed so that its carboxy-terminus is close in space to the amino-terminus of the SH3 domain. The intervening sequence is the PRR, which would be available in this model for binding an $\mathrm{SH} 3$ domain from another protein. $\mathrm{PH}$ domain is shown bound to its $\mathrm{PIP}_{3}$ ligand. $(C)$ Model of Itk adopting the extended conformation seen for Btk in SAXS studies (Marquez et al. 2003). Of note is the fact that the intramolecular PRR/SH3 interaction is sterically allowed and that the SH2-Kinase linker region is likely in an extended conformation and not the active conformation shown in $(B) .(D)$ Native gel electrophoresis for the SH3-SH2-Kinase fragment of Itk and for full length Itk showing ladders indicative of mulitmerization. Sample concentration for both purified proteins is approximately 5 micromolar. (E) Model of Itk multimerization based on the structure of the binary Itk SH3/SH2 complex (PDB code: 2 K79). Doubled headed arrows indicate PH domain self-association. Whether Itk multimerization occurs exclusively at the membrane remains to be determined. It is of note that the $\mathrm{SH} 3 / \mathrm{SH} 2$ interface defined in PDB $2 \mathrm{~K} 79$ is accessible in the models shown in both $(B)$ and $(C)$ suggesting that either configuration could multimerize. In $(B),(C)$ and $(E)$ the amino and carboxy-termimi of full length Itk are indicated by $\mathrm{N}$ and $\mathrm{C}$, respectively.

speculative. It is interesting to note however, that the $\mathrm{PH}-\mathrm{BH}$ domain of Itk extends from the amino-terminus of the PRR region and, within the context of the Csk-based model, the $\mathrm{PH}-\mathrm{BH}$ domain could pack between the $\mathrm{SH} 3$ and $\mathrm{SH} 2$ domains making contact with the small lobe of the kinase domain and/or the $\mathrm{SH} 3-\mathrm{SH} 2 / \mathrm{SH} 2-$ kinase linker regions potentially affecting kinase activity (Joseph et al. 2007b) (Fig. 2B).

\section{Mechanism of Itk Substrate Recognition}

Once activated and assembled within the SLP-76/LAT signaling complex, Itk meets its downstream substrate, PLC $\gamma 1$ (Liu et al. 1998; 
A.H. Andreotti et al.

Schaeffer et al. 1999; Wilcox and Berg 2003; Houtman et al. 2005; Bogin et al. 2007). Itk mediated phosphorylation of Y783 in PLC $\gamma 1$ requires a remote specificity-determining element within the second $\mathrm{SH} 2$ domain of PLC $\gamma 1$ (Joseph et al. 2007c). Mutation in the PLC 11 SH2 domain that disrupts the Itk/ PLC $\gamma 1$ interaction results in decreased PLC $\gamma 1$ activation as measured by calcium flux in Jurkat T cells (Braiman et al. 2006; Min et al. 2009). Earlier work also identified a TCR-regulated association between Itk and PLC $\gamma 1$ involving the SH3 domain of PLC $y 1$ (Perez-Villar and Kanner 1999). Although PLC $\gamma 1$ is the most well established substrate of Itk, additional candidate substrates have been described and include TFII-I (August 2009; Sacristan et al. 2009), Tim-3 (van de Weyer et al. 2006) and T-bet (Hwang et al. 2005); the molecular details of Itk recognition of these substrates has not been elucidated.

\section{Downregulation of Itk Kinase Activity}

Inactivation of kinase activity is an important regulatory feature that must appropriately balance activating signals. Although few negative regulators of Itk have been described, expression of PTEN, a lipid phosphatase, can decrease Itk activity by reducing $\mathrm{PIP}_{3}$ levels (Shan et al. 2000). Negative regulation of Itk by the peptidyl prolyl isomerase, cyclophilin A, has been described (Brazin et al. 2002; Colgan et al. 2004). Interestingly, another peptidyl prolyl isomerase, Pin1 (protein interacting with NIMA1), regulates phosphorylation and steady state levels of Btk (Yu et al. 2006). However, the mechanism of action remains poorly understood for both Pin1 and CypA (Joseph and Andreotti 2009; Mohamed et al. 2009).

As already described, the regulatory domains of the Tec kinases exert a positive influence on the kinase domain in a manner similar to Csk (Fig. 2B) and so conformational rearrangements that uncouple the regulatory domains (particularly the SH2-kinase linker region) from the catalytic domain would downregulate Itk activity. In this context, the only structural data available for any full length Tec kinase comes from small-angle X-ray scattering (SAXS) analysis of Btk (Marquez et al. 2003). These data indicate that an inactive preparation of Btk (Marquez et al. 2003; Lin et al. 2009) adopts an extended conformation in solution with negligible contacts between domains (Fig. 2C). Whether the fully extended configuration derived from SAXS data represent a physiologically relevant state remains to be determined but the available data suggest that a conformational shift of the regulatory domains away from the kinase domain could provide one layer of negative regulation.

In addition to negatively regulating the catalytic domain, the configuration of the inactive kinase might also serve to sequester its ligand binding sites (Pawson and Kofler 2009). The SH3/PXXP interaction, in particular, is constitutive and not controlled by transient phosphorylation/dephosphorylation events. In down-regulated Itk, the $\mathrm{SH} 3$ domain-binding site might be masked in an intramolecular fashion by the adjacent PRR (Andreotti et al. 1997; Laederach et al. 2003) (Fig. 2C). However, it is experimentally difficult to probe the precise role of the PRR in kinase regulation because it is also likely involved in activating interactions with SH3 domain-containing signaling partners (Yang et al. 1995; Bunnell et al. 2000). Efforts that use deletion of the PRR region to probe its regulatory role (Hao and August 2002) are therefore complicated by the dual nature of the PRR.

\section{Regulation of Itk Activity by Multimerization}

Structural studies using different Tec kinase fragments indicate that the noncatalytic regulatory domains interact in an intermolecular fashion driving multimerization in solution (Andreotti et al. 1997; Brazin et al. 2000; Hansson et al. 2001; Laederach et al. 2002; Okoh and Vihinen 2002; Pursglove et al. 2002; Laederach et al. 2003; Severin et al. 2009). For Itk, multimerization is mediated by self-association of the PH domain (Huang et al. 2007) and intermolecular interactions between the $\mathrm{SH} 3$ and $\mathrm{SH} 2$ domains of different Itk molecules (Brazin et al. 2000; Severin et al. 2009). Native gel 
electrophoresis indicates that the full-length Itk molecule, the SH3-SH2-kinase fragment, and the Itk SH3-SH2 fragment all form multimers (Severin et al. 2009) (Fig. 2D). The high resolution structure of the Itk $\mathrm{SH} 3 / \mathrm{SH} 2$ complex has been solved and provides insight into how full length Itk might self-associate (Severin et al. 2009) (Fig. 2E). Functionally, disruption of the $\mathrm{SH} 3 / \mathrm{SH} 2$ interface by mutation reduced oligomerization and increased Itk kinase activity both in vitro and in T cells (Severin et al. 2009; Min et al. 2010). Moreover, both binding experiments and structural data indicate that intermolecular association of Itk is mutually exclusive with binding of SLP-76 to the SH3 and SH2 domains (Brazin et al. 2000; Pletneva et al. 2006; Severin et al. 2009). Thus, downregulation of Itk activity might involve intermolecular self-association whereas multimerization is disfavored for active, SLP-76 bound Itk. The interplay between specific clustering of signaling molecules (Houtman et al. 2006), the formation of TCR microclusters (Bunnell et al. 2006; Seminario and Bunnell 2008) and the specific role of Itk multimerization during T-cell signaling certainly deserve continued attention.

A split YFP/fluorescence complementation approach has been used to probe the different conformational and oligomeric states of Itk in cells (Qi et al. 2006; Qi and August 2009). Itk that is doubly tagged at the amino- and carboxy-termini results in fluorescence complementation in the cytosol and at the membrane. The authors suggest that the observed fluorescence complementation within a single Itk molecule is indicative of a folded compact structure. Taking the linker lengths between Itk and each of the split YFPs (two linkers each $\sim 40 \AA$ ) and the diameter of YFP itself $(\sim 30 \AA)$ into account, fluorescence complementation in this system would occur for distances of approximately $110 \AA$ between the Itk termini. It should be noted that the distance between the aminoand carboxy-termini of Btk in the fully extended model derived from SAXS data is $125 \AA$ and given the flexibility inherent in the extended model (Marquez et al. 2003), it seems likely that fluorescence complementation would be observed for almost any domain arrangement of Itk; compact or extended. Thus, the fluorescence "ruler" used in these experiments is unlikely to discriminate between different domain arrangements.

Intermolecular fluorescence complementation between differentially tagged Itk molecules is consistently observed only at the cell membrane and not in the cytosol (Qi et al. 2006; Qi and August 2009). Although this data alone does not rule out multimerization in the cytosol, the spatial segregation of the stronger fluorescence signal to the membrane is certainly interesting and suggests that Itk clusters are at least stabilized upon or after membrane localization. Notably, Itk autophosphorylation enhances the affinity between the $\mathrm{SH} 3$ and SH2 domains (Joseph et al. 2007a), possibly triggering sequestration of Itk into clusters and down-regulation of kinase activity. Release of Itk from the membrane, promoted by dephosphorylation of $\mathrm{PIP}_{3}$ and the SLP-76/LAT complex (Shan et al. 2000; Baker et al. 2001; Yang et al. 2001; Tomlinson et al. 2004), would then result in decreased local Itk concentration, which could cause Itk oligomers to disassociate into inactive, monomeric species in the cytosol. Regardless of aggregation state, the inactive species would adopt a conformation that decouples the regulatory region (in particular the $\mathrm{SH} 2$ kinase linker) from the Itk kinase domain.

\section{ITK REGULATION OF T-CELL FUNCTION}

Naïve T-Cell Activation is Impaired in the Absence of Itk

The central role of Itk in the LAT-SLP-76 complex suggests that Itk is an important component of TCR signaling. Early studies using primary murine $I t k^{-/-} \mathrm{T}$ cells showed that Itk is required for robust T-cell activation in response to TCR plus costimulatory receptor signaling. However, these studies also revealed that Itk is not absolutely required for all responses downstream of the TCR (Liao and Littman 1995; Liu et al. 1998; Schaeffer et al. 1999). One aspect of this modulatory role for Itk is the partial redundancy between Itk and a 
A.H. Andreotti et al.

second Tec kinase family member, Rlk. Thus, a combined deficiency in both Itk and Rlk results in TCR signaling defects that are significantly more profound than is seen in T cells lacking Itk alone (Schaeffer et al. 1999). Overall, the message from these experiments was that Itk functions to amplify TCR signaling, rather than as an all-or-nothing component of the TCR signaling pathway.

\section{T-Cell Differentiation and Effector Functions are Regulated by Itk}

In spite of the relatively modest impact of the Itk deficiency on naïve T-cell activation, numerous studies have shown that Itk signaling plays a critical role in regulating $\mathrm{T}$-cell differentiation and T-cell effector functions (Fig. 3). The first of these studies showed that $I t k^{-/-} \mathrm{Balb} / \mathrm{c}$ mice were unable to generate the $\mathrm{T}_{\mathrm{H}} 2$ response to

T helper cell development

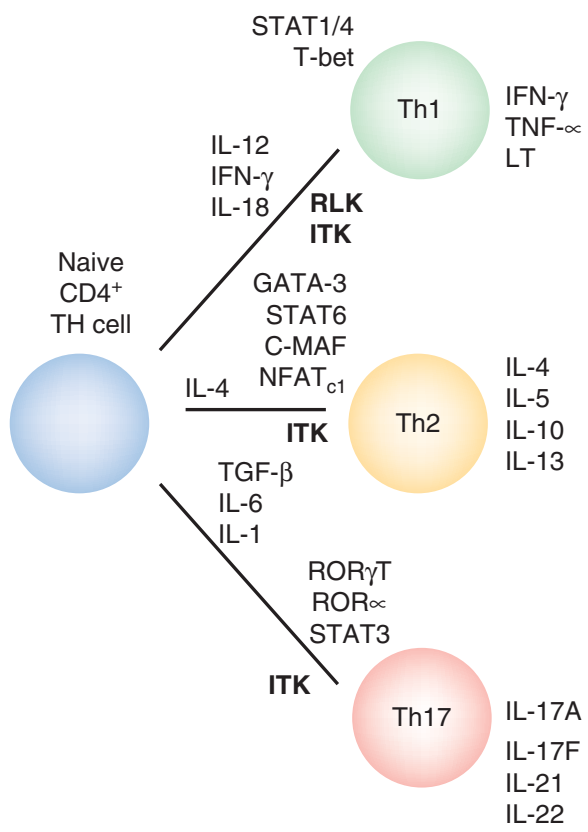

Leishmania major infection typically seen in wild-type Balb/c mice and instead, mounted a protective $\mathrm{T}_{\mathrm{H}} 1$ response that cleared the infection (Fowell et al. 1999). These results highlighted the importance of Itk signaling in the generation of $\mathrm{T}_{\mathrm{H}} 2$ responses, a function of Itk that has been studied in more detail both in vitro and in vivo.

\section{Itk Promotes $\mathrm{T}_{\mathrm{H}} 2$ Differentiation and Cytokine Production}

The initial findings that Itk-deficient mice were unable to mount a protective $\mathrm{T}_{\mathrm{H}} 2$ response to infection were verified in a number of distinct infectious disease systems including Leishmania major in $\mathrm{Itk}^{-/-}$Balb/c mice, as well as Nippostrongylus brasiliensis and Schistosoma mansoni, two parasites that are eliminated by $\mathrm{T}_{\mathrm{H}} 2$-dependent recruitment and activation of granulocytes

ITK-deficiency

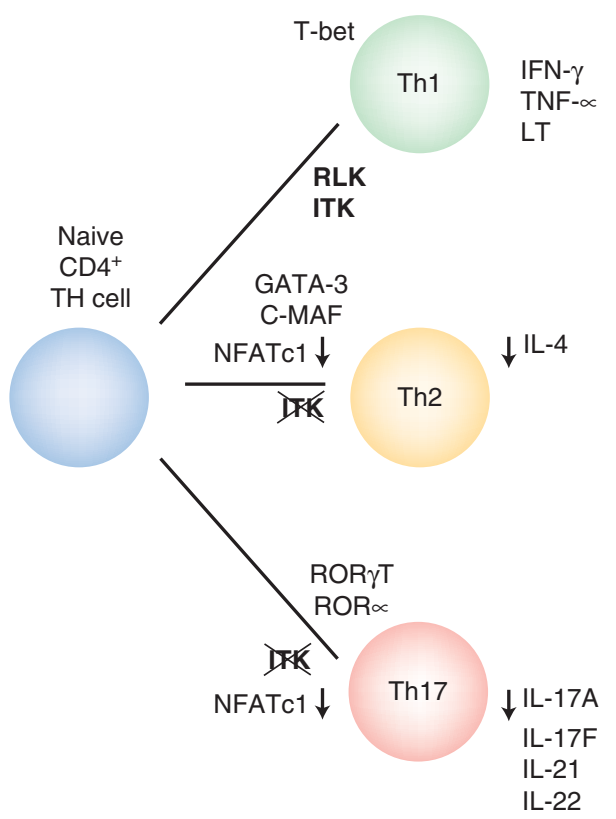

Figure 3. Itk function in T helper cell differentiation. At the left, the three major lineages of effector T cells are shown, along with the cytokine signals and transcription factors that regulate their differentiation from naïve $\mathrm{CD}^{+}{ }^{+} \mathrm{T}$ cells. Unlike $\mathrm{T}_{\mathrm{H}} 1$ cells, which coexpress Itk and Rlk, $\mathrm{T}_{\mathrm{H}} 2$ cells express only Itk. The status of Rlk expression in $\mathrm{T}_{\mathrm{H}} 17$ cells is currently unknown. In the absence of Itk (right panel), $\mathrm{NFAT}_{\mathrm{cl}}$ activity is greatly reduced, leading to impaired production of IL- 4 by $\mathrm{T}_{\mathrm{H}} 2$ cells and IL-17A by $\mathrm{T}_{\mathrm{H}} 17$ cells. Itk $\mathrm{k}^{-/-} \mathrm{T}_{\mathrm{H}} 1$ cells, which continue to express Rlk, have a more modest defect in effector cytokine production. 
(Fowell et al. 1999; Schaeffer et al. 2001). Analyses of cytokine responses of the parasite-specific $\mathrm{T}$ cells from these infected mice indicated that $\mathrm{Itk}^{-/-} \mathrm{T}$ cells produced decreased IL-4, IL-5, and IL-10 (Schaeffer et al. 2001). Similarly, in vitro experiments showed that $I t k^{-/-} \mathrm{Balb} / \mathrm{c}$ $\mathrm{CD}^{+} \mathrm{T}$ cells stimulated under $\mathrm{T}_{\mathrm{H}} 2$-polarizing conditions produced much less IL-4 than their wild-type counterparts (Fowell et al. 1999). These cytokine responses correlated with defective TCR-induced activation of the calciumdependent transcription factor, NFAT, by $I k^{-/}$ $\mathrm{T}$ cells, providing a potential explanation for the reduced Il4 transcription (Fig. 3).

However, it is difficult to infer from these experiments the precise nature of the $\mathrm{T}$-cell defect resulting in impaired protection to parasitic infections. Reductions in T-cell activation, T-cell differentiation, T-cell migration, or elicitation of recall responses at the site of infection could each contribute to the poor protection observed in $\mathrm{Itk}^{-/-}$mice. An additional complication is the presence of a large population of previously activated/memory $\mathrm{CD} 4^{+} \mathrm{T}$ cells in $\mathrm{Itk}^{-/-}$mice; global gene expression analysis has confirmed that $\mathrm{Itk}^{-{ }^{-}-\mathrm{CD}} 4^{+} \mathrm{T}$ cells are not comparable to wild-type $\mathrm{CD} 4^{+} \mathrm{T}$ cells prior to their activation (Blomberg et al. 2009), and thus, might respond differently than naïve $\mathrm{T}$ cells to parasite infections.

Nonetheless, useful information has been gleaned from direct infection of $\mathrm{Itk}^{-/-}$mice with pathogenic microorganisms. One elegant approach to evaluating $\mathrm{T}$ cell defects in the absence of Itk was taken by Au-Yeung and colleagues, who crossed Balb/c Itk/- mice to reporter mice that express GFP under the control of the IL-4 promoter (Au-Yeung et al. 2006). Following infection of these mice with Leishmania major, equal numbers of $\mathrm{CD} 4{ }^{+} \mathrm{GFP}^{+} \mathrm{T}$ cells were found at the sites of infection in wild-type versus $I t k^{-/-}$mice, indicating that Itk was not required for the initiation of the $\mathrm{T}_{\mathrm{H}} 2$ response or for the migration of IL-4-competent T cells to these sites. Instead, the effector T-cell recall response at the sites of infection were impaired in the absence of Itk, leading to reduced IL-4 production by $\mathrm{Itk}^{-/-} \mathrm{T}$ cells following restimulation. However, these studies are not in complete agreement with an independent set of experiments examining T-cell-mediated airway hyperresponsiveness in $\mathrm{Itk}^{-/-}$mice (Mueller and August 2003). In this system, in addition to impaired $\mathrm{T}_{\mathrm{H}} 2$ cytokine production, $\mathrm{T}$-cell recruitment to the lungs was also impaired following inhaled antigen challenge in $\mathrm{Itk}^{-/-}$mice compared to controls. Interestingly, a partial inhibition of Itk kinase activity was able to block T-cell migration to the lung in this model system, but had no effect on the priming of $\mathrm{T}_{\mathrm{H}} 2$ effector responses in secondary lymphoid organs (Sahu et al. 2008a). These findings indicate roles for Itk in both T-cell priming and T-cell migration, findings that are supported by studies showing a role for Itk in signaling downstream of chemokine receptors (Fischer et al. 2004; Takesono et al. 2004).

These in vivo experiments have been complemented by a series of in vitro experiments performed with naïve $I t k^{-/-} \mathrm{CD} 4^{+} \mathrm{T}$ cells. All of these studies agreed that $I t k^{-/-} \mathrm{CD} 4^{+} \mathrm{T}$ cells produced substantially less IL-4, IL-5, and IL-13 than wild-type T cells, even after differentiation in a powerful $\mathrm{T}_{\mathrm{H}} 2$ polarizing environment (Fowell et al. 1999; Schaeffer et al. 2001; Miller et al. 2004; Au-Yeung et al. 2006). In these studies, the defects in effector cytokine production were not because of impaired $\mathrm{T}_{\mathrm{H}} 2$ differentiation, as molecular analyses indicated that $I t k^{-/-} \mathrm{T}$ cells polarized into the $\mathrm{T}_{\mathrm{H}} 2$ lineage showed all of the hallmarks of bona fide $\mathrm{T}_{\mathrm{H}} 2$ effector cells (Schaeffer et al. 2001; Miller et al. 2004; Au-Yeung et al. 2006). Interestingly, the requirement for Itk in effector cytokine production is shared by $\alpha \beta \mathrm{TCR}^{+} \mathrm{NKT}$ cells specific for $\alpha$-galactosyl ceramide bound to CD1d; in the absence of Itk, NKT cells stimulated in vivo or in vitro produce substantially less IL-4 or IFN $\gamma$ than wild-type NKT cells (Au-Yeung and Fowell 2007; Felices and Berg 2008).

\section{$T_{H}$ 1 Differentiation and Effector \\ Functions are Modestly Impaired in the Absence of Itk}

Unlike the essential role for Itk in protective immunity to helminthic parasites, Itk signaling in $\mathrm{T}$ cells is largely dispensible for protective 
A.H. Andreotti et al.

$\mathrm{CD} 4^{+} \mathrm{T}_{\mathrm{H}} 1$ responses to intracellular pathogens. Thus, $\mathrm{Itk}^{-/-}$mice clear infections of Leishmania major, and are only modestly more susceptible to sublethal doses of Toxoplasma gondii than wild-type mice (Fowell et al. 1999; Schaeffer et al. 1999). These observations may reflect the fact that IFN $\gamma$ production by $I t k^{-/-} \mathrm{CD} 4^{+} \mathrm{T}$ cells is not reduced to the same extent as production of $\mathrm{T}_{\mathrm{H}} 2$ cytokines (Fowell et al. 1999; Schaeffer et al. 2001; Miller et al. 2004; Au-Yeung et al. 2006). Indeed, under certain conditions that normally lead to $\mathrm{T}_{\mathrm{H}} 2$ cytokine production, such as stimulation with altered peptide ligands, $\mathrm{Itk}^{-/-} \mathrm{CD} 4^{+} \mathrm{T}$ cells produce IFN- $\gamma$ (Miller et al. 2004). A second aspect of this differential requirement for Itk in $\mathrm{T}_{\mathrm{H}} 1$ versus $\mathrm{T}_{\mathrm{H}} 2$ effector responses is the interesting expression pattern of the two predominant Tec kinases in T cells, Itk and Rlk (Fig. 3). Unlike naïve T cells which express both Itk and Rlk, $\mathrm{T}_{\mathrm{H}} 2$ effector cells lose Rlk and express only Itk; in fact, the levels of Itk are several-fold increased in $\mathrm{T}_{\mathrm{H}} 2$ cells compared to naïve T cells (Miller et al. 2004). In contrast, $\mathrm{T}_{\mathrm{H}} 1$ effector cells continue to express both of these Tec kinases. As a consequence, whereas $I t k^{-/-} \mathrm{T}_{\mathrm{H}} 1$ cells continue to express $\mathrm{Rlk}, \mathrm{Itk}^{-/-}$ $\mathrm{T}_{\mathrm{H}} 2$ cells lack both Itk and Rlk, thus accounting for the more severe functional defect observed in $I t k^{-/-} \mathrm{T}_{\mathrm{H}} 2$ responses. Corroborating this notion, ectopic expression of Rlk in effector $\mathrm{T}_{\mathrm{H}} 2$ cells restores wild-type $\mathrm{T}$ cell responses in $\mathrm{Itk}^{-/-}$mice injected with Schistosoma mansoni eggs or immunized to induce allergic airway hypersensitivity (Sahu et al. 2008b).

\section{Itk Is Required for IL-17A Production in $\mathrm{T}_{\mathrm{H}} 17$ Effector Cells}

In addition to the global defects in effector T-cell responses described above for $\mathrm{T}_{\mathrm{H}} 2$, and to a lesser extent, $\mathrm{T}_{\mathrm{H}} 1$ responses, $\mathrm{T}$ cells lacking Itk display more selective alterations in cytokine production that highlight the complex nature of the signaling pathways that regulate T-cell effector responses. One recent example is the role of Itk in the regulation of cytokine production by $\mathrm{T}_{\mathrm{H}} 17$ cells, a recently recognized CD4 effector $\mathrm{T}$-cell lineage that differentiates in response to IL- 6 and TGF- $\beta$ and expresses the pro-inflammatory cytokines IL-17A, IL-17F, IL-21 and IL-22 (Korn et al. 2009). $\mathrm{T}_{\mathrm{H}} 17$ cells are important for antimicrobial activity, particularly in the gastrointestinal system, but are also hallmarks of inflammation involved in multiple autoimmune disorders.

Although the requirements for cytokine signals for $\mathrm{T}_{\mathrm{H}} 17$ differentiation have been extensively examined, the contribution of TCR signaling to the regulation of $\mathrm{T}_{\mathrm{H}} 17$ cytokine production was unknown. To evaluate this question, naïve $\mathrm{CD}^{+} \mathrm{T}$ cells from $\mathrm{Itk}^{-/-}$and $R l k^{-/-} I t k^{-/-}$mice were differentiated under $\mathrm{T}_{\mathrm{H}} 1$ and $\mathrm{T}_{\mathrm{H}} 17$ polarizing conditions, and cytokine production evaluated by intracellular staining (Gomez-Rodriguez et al. 2009). Although both cell types could generate large percentages of IFN $\gamma$ producing $\mathrm{T}_{\mathrm{H}} 1$ cells, $\mathrm{Itk}^{-/-}$and even more dramatically $R l k^{-/-} I t k^{-/-} \mathrm{T}$ cells showed reduced IL-17A production. These defects did not appear to be because of altered thymic development, because they could be reversed by re-introduction of Itk by retroviral transduction before $\mathrm{T}_{\mathrm{H}} 17$ differentiation. Further analyses showed decreased Ill7a message in $\mathrm{Itk}^{-/-} \mathrm{T}$ cells (Fig. 3). However, surprisingly, expression of other $\mathrm{T}_{\mathrm{H}} 17$ cytokines including the closely linked Ill7f gene, was relatively intact, as was the expression of genes encoding the master regulators ROR $\gamma t$ and ROR $\alpha$. Although phosphorylation of STAT3 in response to IL- 6 was slightly attenuated in Itk-deficient $\mathrm{T}$ cells, re-expression of a constitutively activated STAT3 construct did not restore normal IL-17A production.

The selective role for Itk in IL-17A production resulted from a requirement for robust calcium signaling, leading to NFAT activation, in the transcription of the Il17a gene (Fig. 3). Thus, differentiation of $I t k^{-/-} \mathrm{T}$ cells in the presence of anti-CD3 plus ionomycin, which can rescue $\mathrm{Ca}^{2+}$ mobilization in Itk-deficient T cells (Liu et al. 1998), did restore IL-17A production, directly implicating defective TCR-driven $\mathrm{Ca}^{2+}$ mobilization in this phenotype (GomezRodriguez et al. 2009). Supporting this idea, stimulation of wild-type $\mathrm{T}$ cells with decreasing amounts of anti-CD3 during differentiation preferentially reduced expression of IL17A, whereas leaving IL-17F relatively spared. 
Similarly, differentiation of wild-type $\mathrm{T}$ cells in the presence of low-dose CyclosporinA or FK506, two inhibitors of Calcineurin that prevent NFAT activation (Winslow et al. 2003), also preferentially decreased IL-17A expression. Conversely, expression of a constitutively active mutant of $\mathrm{NFAT}_{\mathrm{cl}}$ (Neal and Clipstone 2003) restored IL-17A production by $I_{t k^{-/-}} \mathrm{T}_{\mathrm{H}} 17$ cells, suggesting that Itk-mediated activation of NFAT contributes to the regulation of IL-17A. Sequence analyses showed a conserved NFAT binding site located $3.5 \mathrm{~kb}$ upstream of the start site of the Ill $\mathrm{a}$ gene and ChIP analyses showed that this site was occupied in wild-type but not Itk-deficient cells differentiated under $\mathrm{T}_{\mathrm{H}} 17$ conditions. Although potential NFAT binding sites were found upstream of the Illif gene, none were conserved cross-species. Nonetheless, conserved noncoding sequences in the region around both the linked Ill7a and Ill7f genes showed epigenetic modifications suggestive of open chromatin conformations (Wilson et al. 2009).

These results suggest that a TCR-driven pathway involving Itk-mediated regulation of $\mathrm{Ca}^{2+}$ and NFAT is required for full expression of IL-17A and that this pathway distinguishes expression of different $\mathrm{T}_{\mathrm{H}} 17$ cytokines. These data support the growing view that there are distinct subclasses of $\mathrm{T}_{\mathrm{H}} 17$ cells that produce overlapping sets of cytokines based upon distinct inputs. Thus, TCR signaling may be particularly important for expression of IL-17A, which is more strongly proinflammatory than IL-17F (Yang et al. 2008; Ishigame et al. 2009). This regulation operates during the differentiation of $\mathrm{T}_{\mathrm{H}} 17$ cells, because the defect in IL-17A production is seen even upon restimulation of cells with PMA and ionomycin (Gomez-Rodriguez et al. 2009). NFAT $\mathrm{cl}$ autoregulates its own expression and previous data showed defective $\mathrm{NFAT}_{\mathrm{cl}}$ induction in Itk-deficient cells (Nurieva et al. 2007), perhaps accounting for the requirement for Itk during $\mathrm{T}_{\mathrm{H}} 17$ differentiation. Alternatively, other chromatin remodeling factors that are recruited by transcription factors, including the BRG proteins, may not assemble properly on the IL-17A locus in the absence of efficient NFAT activation (Berg 2009). Although the exact mechanism of this defect awaits further study, these detailed investigations of Itkdeficient $\mathrm{T}$ lymphocytes have revealed another feature of how TCR signaling can affect the differentiation of distinct cytokine producing cells.

\section{TCR Signaling in CD8 ${ }^{+}$T Cells Requires Itk}

Although fewer studies have addressed the role of Itk in $\mathrm{CD} 8{ }^{+} \mathrm{T}$-cell responses, the conclusions thus far indicate that primary responses to viral infection are largely intact in the absence of Itk, or Itk and Rlk (Bachmann et al. 1997; Atherly et al. 2006). Biochemical studies show that $\mathrm{Itk}^{-/-}$and $\mathrm{Rlk}^{-/-} \mathrm{Itk}^{-/-} \mathrm{CD}^{+} \mathrm{T}$ cells share a similar deficiency in TCR-induced PLC- $\gamma 1$ activation, calcium mobilization, ERK activation, and cytokine production as $\mathrm{CD} 4^{+} \mathrm{T}$ cells lacking the Tec kinases (Atherly et al. 2006). Nonetheless, $\mathrm{Itk}^{-/-}$mice do mount protective immune responses to LCMV, vaccinia virus, and VSV, and $\mathrm{Rlk}^{-/-} \mathrm{Itk^{-/- }}$ mice to LCMV, although kinetics of viral clearance were often slightly delayed. Tracking of virus-specific $\mathrm{CD}^{+} \mathrm{T}$ cells indicated that $\mathrm{Itk}^{-/-}$and

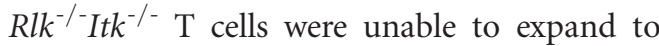
the extent seen with wild-type $\mathrm{T}$ cells, resulting in an overall deficit in the magnitude of the $\mathrm{CD}^{+}{ }^{\mathrm{T}} \mathrm{T}$-cell response. This reduction in T-cell expansion could not be accounted for by impaired $\mathrm{CD}^{+} \mathrm{T}$ cell help in $\mathrm{Itk}^{-/-}$mice, as adoptive transfer of wild-type LCMV-immune $\mathrm{T}$ cells $\left(\mathrm{CD}^{+}{ }^{+}\right.$and $\left.\mathrm{CD} 8^{+}\right)$into $\mathrm{It}^{-/-}$mice prior to LCMV challenge was unable to rescue the $\mathrm{CD}^{+} \mathrm{T}$-cell defects. In addition, the impaired response of $\mathrm{Itk}^{-/-} \mathrm{CD} 8^{+} \mathrm{T}$-cells was not because of the predominant population of "innate-like" $\mathrm{CD}^{+} \mathrm{T}$-cells present in these mice (see the following), as OT-1 TCR transgenic $\mathrm{Itk}^{-/-} \mathrm{CD}^{+}$ T-cells, which develop as conventional naïve T-cells, also shared the defect seen with polyclonal $\mathrm{Itk}^{-/-} \mathrm{CD}^{+} \mathrm{T}$-cells in non-TCR transgenic mice. It still remains to be determined whether It $\mathrm{k}^{-/-} \mathrm{CD} 8^{+} \mathrm{T}$-cells can generate functional memory cells. Although virus-specific T-cells persist in $\mathrm{Itk}^{-/-}$mice well after virus has been cleared from the animals, the ability of these cells to provide protection, and to mount an effective recall response, has not yet been tested. 
A.H. Andreotti et al.

This issue is complex, as defects in $\mathrm{Itk}^{-/-} \mathrm{CD} 4^{+}$ T-cells could impact the generation of robust memory $\mathrm{CD} 8{ }^{+} \mathrm{T}$-cells; thus, appropriate studies will be required to distinguish $\mathrm{CD} 4^{+} \mathrm{T}$ cell-intrinsic from $\mathrm{CD}^{+}$T-cell-intrinsic contributions to antiviral memory responses.

\section{TEC KINASES IN T-CELL DEVELOPMENT}

\section{Role of Itk and RIk in Conventional T-cell Development}

TCR signaling plays a critical role in the development of $\mathrm{T}$ cells within the thymus, where the strength or duration of TCR signaling helps determine the survival, maturation, and differentiation of thymocytes into mature $\mathrm{T}$ cells. Double negative $\mathrm{CD} 4^{-} \mathrm{CD} 8{ }^{-}$(DN) cells that have rearranged their TCR $\beta$ chains must receive competent signals through the pre-TCR to progress through the DN3 stage and expand in the DN4 to double positive (DP) transition (Ciofani and Zuniga-Pflucker 2006). At the double positive stage, TCR signaling regulates cell survival and differentiation of conventional $\mathrm{T}$ cells (Jameson et al. 1995). Thymocytes that receive very poor or no TCR signals undergo "death by neglect." Thymocytes that receive strong TCR signals, as from agonist peptides, particularly in the context of costimulation, undergo negative selection and also die within the thymus. Only thymocytes that receive weak but adequate signals will progress onto CD4/CD8 selection, where the duration of TCR signaling, in large part dictated by the expression patterns of the co-receptors $\mathrm{CD} 4$ and CD8 upon TCR engagement, will determine their ultimate lineage as CD4 or CD8 single positive (SP) cells (Bosselut 2004).

It is therefore not surprising that $I t k^{-/-}$and $\mathrm{Rlk}^{-/-} \mathrm{Itk}^{-/-} \mathrm{T}$ cells show altered thymocyte development (Fig. 4). It $\mathrm{k}^{-/-}$mice have smaller thymi and show phenotypes consistent with impaired pre-TCR signaling. Although these defects are relatively subtle, competitive bone marrow transfers using mixtures of $\mathrm{WT}$ and $I t k^{-/-}$bone marrow indicated that both $I_{t} k^{-/-}$ and $\mathrm{Rlk}^{-/-} \mathrm{Itk^{-/- }}$ cells had a selective disadvantage at the DN-DP transition (Lucas et al.
2007). However, Rlk $^{-/-} I t k^{-/-} \mathrm{T}$ cells also showed a competitive advantage compared to WT cells at earlier stages ( prior to DN3), perhaps reflecting a negative signaling role for Rlk in cell survival/cytokine signaling pathways.

Defects in positive selection of thymocytes lacking Itk have been shown using a variety of MHC Class I and Class II-restricted TCR transgenes (Liao and Littman 1995; Schaeffer et al. 2000; Lucas et al. 2002; Lucas et al. 2003). The extent of these defects depended on the selecting TCR, with the weakest selecting TCRs showing the largest effects (Lucas et al. 2002). Defects in positive selection were exacerbated in $\mathrm{Rlk}^{-/-} \mathrm{Itk^{-/- }}$ mice, providing evidence that these genes are partially redundant, and supporting the idea that decreased TCR signaling reduces positive selection of conventional $\mathrm{T}$ cells (Schaeffer et al. 2000). Supporting partial redundancy of these genes, overexpression of Txk/Rlk partially rescued positive selection defects in $I t k^{-/-}$mice (Sommers et al. 1999).

Itk-deficient animals also show reduced or delayed negative selection in multiple TCR transgenic systems (Liao and Littman 1995; Schaeffer et al. 2000; Lucas et al. 2002). In $\mathrm{Rlk}^{-/-} \mathrm{Itk}^{-/-}$mice, negative selection is more clearly impaired, leading to positive selection of normally deleted HY TCR transgenic cells in male $\mathrm{Rlk}^{-/-} \mathrm{Itk}^{-/-}$mice (Schaeffer et al. 2000). These data support a model where negative selection is converted to positive selection in the context of impaired TCR signaling and may account for the increased SP cells in $\mathrm{Rlk}^{-/-} \mathrm{Itk}^{-/-}$ mice.

\section{Development of Innate T-Lymphocyte Populations}

Recent data have revealed surprising new findings on thymic selection in mice deficient in Itk and Rlk (Atherly et al. 2006; Broussard et al. 2006; Dubois et al. 2006; Berg 2007; Hu et al. 2007). Although $I t k^{-/-}$and $\mathrm{Rlk}^{-/-} \mathrm{Itk}^{-/-}$ mice show decreased positive selection of conventional T cells using both MHC Class I and Class II-restricted TCR transgenes, surprisingly, $\mathrm{Itk}^{-/-}$and $\mathrm{Rlk}^{-/-} \mathrm{Itk^{-/- }}$ mice have increased numbers of CD8 SP cells (Liao and Littman 1995; 
Tec Kinase Itk in T-Cell Signaling

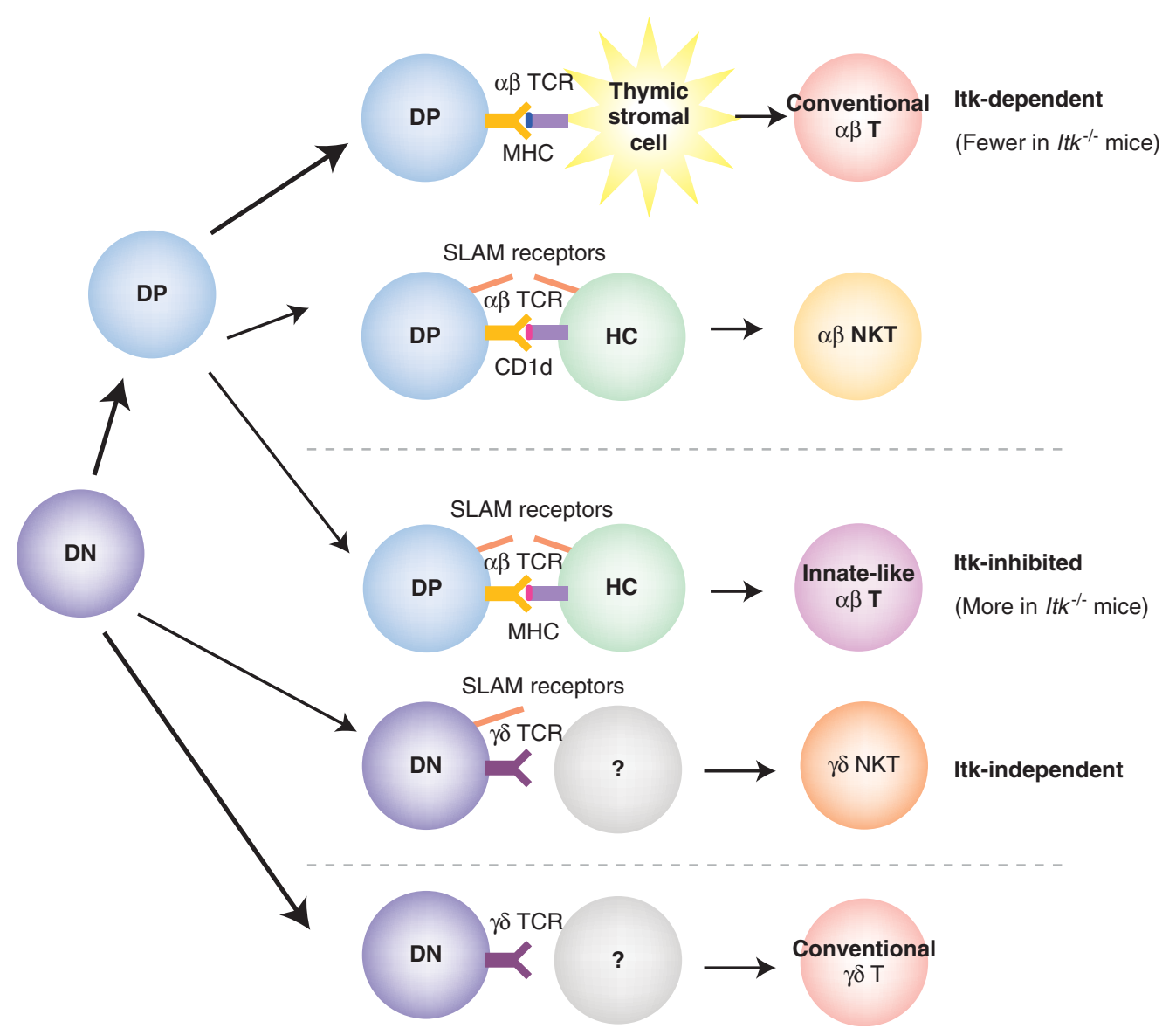

Figure 4. Regulation of T-cell lineages by Itk. In the thymus, progenitor T cells (CD4 ${ }^{-} \mathrm{CD} 8{ }^{-} \mathrm{CD} 3^{-}$; DN) develop into $\gamma \delta \mathrm{T}$ cells and $\alpha \beta \mathrm{T}$ cells. Cells developing in the $\alpha \beta$ T-cell lineage progress through an intermediate $\mathrm{CD} 4^{+} \mathrm{CD}^{+}$(DP) stage prior to their maturation into mature conventional $\alpha \beta$ T cells, CD1d-restricted $\alpha \beta$ NKT cells and other subsets of innate-like $\alpha \beta$ T cells. Conventional $\alpha \beta$ T cells, which are selected on classical MHC molecules expressed on thymic stromal cells, and $\alpha \beta$ NKT cells, which are selected on the MHC class IB molecule, CD1d, expressed on hematopoietic cells (HC) and dependent on SLAM receptor signaling, are greatly reduced in the absence of Itk. In contrast, innate-like $\alpha \beta \mathrm{T}$ cells, which are also selected by recognition of MHC molecules on HC and require SLAM receptor signaling, and "innate-like" $\gamma \delta \mathrm{T}$ cells $(\gamma \delta \mathrm{NKT})$ are substantially increased in number in $I t \mathrm{k}^{-/-}$mice. A third subset of cells, illustrated by conventional $\gamma \delta \mathrm{T}$ cells, appear unaffected by the presence versus the absence of Itk. Currently, the cell-cell interactions required for $\gamma \delta$ T-cell development are unknown.

Schaeffer et al. 2000; Lucas et al. 2002). Further examination of these CD8 SP populations suggested that these cells do not resemble conventional naive CD8 SP thymocytes. Instead, virtually all of the CD8 SP thymocytes in these mice showed markers seen on memory or activated $\mathrm{T}$ cells, including CD44 and CD122 (the IL-2R $\beta$ chain), and rapidly expressed cytokines upon activation (Atherly et al. 2006; Broussard et al. 2006; Dubois et al. 2006; Hu et al. 2007). These phenotypes are characteristic of memory cells in the periphery-however, developmental studies and fetal thymic organ cultures provided evidence that Itk-deficient CD8 cells developed these characteristics within the thymus (Atherly et al. 2006; Broussard et al. 2006; Dubois et al. 
A.H. Andreotti et al.

2006). Although genetic crosses showed a requirement for MHC Class I for their development, transfers of bone marrow from $\mathrm{Itk}^{-/-}$or $\mathrm{Rlk}^{-/-} \mathrm{Itk^{-/- }}$ mice into irradiated $\beta 2 \mathrm{~m}$-deficient mice, which lack MHC-Class I on their radioresistant thymic stroma, showed that $\mathrm{Itk}^{-/-}$and $\mathrm{Rlk}^{-/-} \mathrm{Itk}^{-/-} \mathrm{CD} 8^{+}$thymocytes could be selected on hematopoietically derived cells (Broussard et al. 2006). Although these observations are atypical for conventional thymocytes, these features are all reminiscent of NKT cells and other related innate $\mathrm{T}$-cell lineages; thus, many innate T-cell lineages have been shown to be selected on double-positive thymocytes, to express activation or memory cell markers, and to rapidly produce cytokines even in the thymus (Berg 2007). Like NKT cells, Itk $k^{-/-}$and $\mathrm{Rlk}^{-/-} \mathrm{Itk}^{-/-}$ $\mathrm{CD}^{+}$cells also expressed NK cell markers and high levels of the transcription factor Eosmesodermin, and were dependent on IL-15 (Atherly et al. 2006; Dubois et al. 2006). Moreover, like NKT cells, development of these CD8 cells was dependent on SAP, a small adaptor molecule that is required for signaling from the SLAM family of receptors that are expressed on hematopoietic cells, but not on the thymic epithelium (Horai et al. 2007). Together these characteristics suggested that Itk-deficiency led to the preferential selection of an innate CD8 cell population on hematopoietic cells within the thymus (Fig. 4).

Although this phenotype is primarily seen in CD8 cells, there is also a small population of $\mathrm{CD} 4$ cells that show these properties in $\mathrm{Itk}^{-/}$ mice. These $\mathrm{CD} 44^{\mathrm{hi}} \mathrm{CD} 4^{+}$cells are also dependent on SAP and express PLZF, a transcription factor responsible for the innate characteristics of NKT cells (PLS and LJB, unpublished data and Broussard et al. 2006; Hu and August 2008; Raberger et al. 2008). Although the selecting cell population for the innate type $\mathrm{T}$ cells in $\mathrm{Itk}^{-/-}$mice is yet undetermined, the large number of CD8 cells with this characteristic (and relatively low numbers of CD4 cells) suggests that it is likely to be DP thymocytes, which express MHC Class I but not Class II, and are the selecting cells for NKT cells (Bendelac 1995).

Why loss of Itk leads to the preferential development of CD8 cells with this phenotype is not clear. Reciprocal transfers of $I t k^{-/-} \beta 2 \mathrm{~m}^{-/-}$ bone marrow provided evidence that the development of these innate phenotypes required selection on hematopoietic cells (Horai et al. 2007). One possibility is that poor selection of conventional thymocytes could permit selection or expansion of cells selected on hematopoietic cells. However, transfer of WT bone marrow into irradiated $\beta 2 \mathrm{~m}$-deficient hosts prevents selection of conventional $\mathrm{CD} 8^{+} \mathrm{T}$ cells and yet does not give rise to a large number of innate CD8 cells, suggesting that development of these cells is normally suppressed. Given the rapid production of cytokines showed by these cells, it is likely that the generation of these cells may be under tight control.

Several theories could account for the development of this population in $\mathrm{Itk}^{-/-}$mice. Itk could play a negative role in signaling pathways required for the development of these lineages, such those downstream of SLAM family receptors. Alternatively, these cells might normally be deleted in wild-type animals-negative selection can occur on hematopoietic cells, which express costimulatory molecules, such as CD28, thought to be important in this process (Punt et al. 1994). Alternatively, defective TCR signaling may make these cells more susceptible to signals from costimulatory molecules, such as SLAM family members, or cytokines that may be required either for selection or development of these phenotypes (Atherly et al. 2006; Dubois et al. 2006; Horai et al. 2007). Further analyses will provide clues to the regulation of these interesting lineages that appear to be at the boundary of innate and adaptive immune responses (Berg 2007).

\section{Itk Signaling Regulates $\alpha \beta$ and $\gamma \delta$ NKT-Cell Maturation}

In addition to defects in the development and selection of conventional naïve $\mathrm{CD} 4^{+}$and $\mathrm{CD}^{+}{ }^{+}$T-cells, $\alpha \beta \mathrm{TCR}^{+}$NKT-cell maturation is also impaired in the absence of Itk and Rlk (Gadue and Stein 2002; Au-Yeung and Fowell 2007; Felices and Berg 2008; and Fig. 5). In these Tec kinase-deficient mice, $\alpha \beta$ NKT cell numbers are substantially reduced; furthermore, of 
the cells that remain, few represent the most mature $\alpha \beta$ NKT subset characterized by high expression of NK1.1 and CD122, and downregulation of CD4. Itk $\mathrm{k}^{-/-}$and $\mathrm{Itk}^{-/-} \mathrm{Rlk}^{-/-} \mathrm{NKT}$ cells also show poor responses to TCR stimulation, producing little to no IL-4 and IFN $\gamma$ following in vivo activation. Thus, similar to conventional $\alpha \beta$ T cells, $\alpha \beta$ NKT cells require Tec kinases for their development and function.

In stark contrast to the requirements for $\alpha \beta \mathrm{TCR}^{+} \mathrm{T}$ cells, the development of $\gamma \delta \mathrm{T}$ cells does not require Itk signaling (Fig. 4). The major $\gamma \delta$ T-cell populations that arise in the fetus and adult are largely unchanged in $\mathrm{It}^{-/}$ mice (Felices et al. 2009; C. Yin and LJB, unpub. observ.). Indeed, overall $\gamma \delta \dot{\delta}$ cell numbers in $\mathrm{Itk}^{-/-}$mice are significantly increased compared to wild-type mice, because of dramatic increases in one particular $\gamma \delta$ T-cell subset, the $\gamma \delta$ NKT cells (Felices et al. 2009; Qi et al. 2009). This subset expresses the Vy1.1/V86.3 TCR; however, in all other regards, these $\gamma \delta \mathrm{T}$ cells share characteristics of CD1d-specific $\alpha \beta$ NKT cells rather than traits associated with most adultderived $\gamma \delta \mathrm{T}$ cells (Vicari et al. 1996; Azuara et al. 1997; Lees et al. 2001). For instance, the majority of $\gamma \delta$ NKT cells express CD4, NK1.1, and the signature NKT cell transcription factor, PLZF (Felices et al. 2009; Kreslavsky et al. 2009). As a result, $\gamma \delta$ NKT cells, like their $\alpha \beta$ NKT cell counterparts, produce both IFN $\gamma$ and $\mathrm{T}_{\mathrm{H}} 2$ cytokines. In addition, these cells preferentially home to the liver, rather than to lymphoid organs such as the spleen (Lees et al. 2001; Felices et al. 2009).

Surprisingly, this expanded population of $\gamma \delta$ NKT cells is responsible for a spontaneous hyper-IgE syndrome observed in $I t k^{-/-}$mice (Felices et al. 2009; Qi et al. 2009). When $I_{t k^{-/-}}$mice are crossed to mice lacking $\gamma \delta \mathrm{T}$ cells, the elevated serum IgE and germinal center hyperplasia seen in $\mathrm{It}^{-/-}$mice disappear. $\mathrm{Itk}^{-/-}$ splenic $\gamma \delta$ NKT cells constitutively express ICOS, and readily upregulate CD40-ligand and OX40 following $\gamma \delta$ TCR stimulation in vitro (Felices et al. 2009). These findings suggest that $I t k^{-/-} \gamma \delta$ NKT cells are being activated in vivo, allowing them to provide $\mathrm{T}$ cell help to B cells and secrete cytokines that promote switching to IgE. As with the majority of $\gamma \delta$ $\mathrm{T}$ cells, the ligand recognized by the $\mathrm{V} \gamma 1.1 /$ V $\delta 6.3^{+}$TCR is unknown, nor is it known whether activation of these cells requires signaling through the $\gamma \delta$ TCR.

These findings raise several interesting issues regarding the development and signaling properties of $\gamma \delta \mathrm{T}$ cells. In contrast to $\alpha \beta \mathrm{T}$ cells, $\gamma \delta \mathrm{T}$ cells are not reduced in the absence of Itk; further, the $\gamma \delta$ NKT cell population is, in fact, greatly expanded. These data indicate that the signals regulating $\gamma \delta \mathrm{T}$-cell development do not require Itk, a situation comparable to that seen for innate $\mathrm{CD}^{+} \alpha \beta$ T cells. The expansion of both the $\gamma \delta \mathrm{NKT}$ and the innate $\mathrm{CD} 8^{+}$population in $\mathrm{Itk}^{-/}$mice may reflect the fact that the majority of these cells normally undergo negative selection, but that their deletion is impaired in the absence of Itk.

A second interesting issue is the apparently robust TCR signaling in $I t k^{-/-} \gamma \delta$ T cells. $\alpha \beta$ T cells lacking Itk have substantially reduced responses to TCR signaling, particularly in their ability to synthesize effector cytokines. $I t k^{-1-} \gamma \delta$ $\mathrm{T}$ cells, however, produce copious amounts of cytokines in response to $\gamma \delta$ TCR stimulation. These data suggest that the biochemical pathways downstream of the $\gamma \delta$ TCR are likely distinct from those in $\alpha \beta$ T cells. Consistent with this idea, mice carrying a mutant version of the adapter protein LAT also have few $\alpha \beta$ T cells but greatly increased numbers of $\gamma \delta \mathrm{T}$ cells that overproduce $\mathrm{T}_{\mathrm{H}} 2$ cytokines; further, these mice share the hyper-IgE syndrome seen in $\mathrm{Itk}^{-/-}$mice (Nunez-Cruz et al. 2003). This LAT mutant is lacking a critical tyrosine in the cytoplasmic tail that is essential for efficient TCR signaling in $\alpha \beta \mathrm{T}$ cells, reinforcing the notion that $\alpha \dot{\beta}$ and $\gamma \delta$ TCR signaling have distinct biochemical requirements.

\section{ITK AND HUMAN DISEASE}

Although mutations affecting Btk were identified as the cause of X-linked Agammaglobulinemia 17 years ago (Rawlings et al. 1993; Thomas et al. 1993; Tsukada et al. 1993; Vetrie et al. 1993), alterations in Itk have only recently been associated with human disorders. These 
A.H. Andreotti et al.

include Itk promoter polymorphisms associated with atopy (Graves et al. 2005) and the expression of an Itk-Syk fusion protein generated by a chromosomal translocation in T-cell lymphomas (Streubel et al. 2006); in this latter case, the Itk PH domain becomes fused to the kinase domain of Syk, leading to constitutive activation of the kinase. Most recently, a mutation affecting Itk was found in 2 siblings who died from fatal Epstein-Barr Virus infection (Huck et al. 2009). This mutation changes a single amino acid in the Itk SH2 domain and destabilizes the Itk protein. Although the basis for this particular immunodeficiency is unknown, it may be related to Itk function in cytotoxic $\mathrm{CD}^{+} \mathrm{T}$ cells (Bachmann et al. 1997; Atherly et al. 2006). Importantly, the implication of Itk in a human primary immunodeficiency has validated its role as a critical regulator of $\mathrm{T}$ lymphocyte function. Given the depth of information on lymphocyte biology provided through the study of Tec kinases, it is clear that their study will continue to provide important insights into the signaling pathways involved in immune cell development, homeostasis and function.

\section{ACKNOWLEDGMENTS}

This work was supported by grants from the National Institutes of Health (AI37584 and AI46564 to LJB and AI043957 and AI075150 to AHA) and by intramural funds from the NHGRI/NIH (PLS). We thank Julia Fekecs for assistance with graphic illustrations.

\section{REFERENCES}

Andreotti AH, Bunnell SC, Feng S, Berg LJ, Schreiber SL. 1997. Regulatory intramolecular association in a tyrosine kinase of the Tec family. Nature 385: 93-97.

Atherly LO, Brehm MA, Welsh RM, Berg LJ. 2006. Tec kinases Itk and Rlk are required for CD8 $+\mathrm{T}$ cell responses to virus infection independent of their role in $\mathrm{CD} 4+\mathrm{T}$ cell help. J Immunol 176: 1571-1581.

Au-Yeung BB, Deindl S, Hsu LY, Palacios EH, Levin SE, Kuriyan J, Weiss A. 2009. The structure, regulation, and function of ZAP-70. Immunol Rev 228: 41-57.

Au-Yeung BB, Fowell DJ. 2007. A key role for Itk in both IFN gamma and IL-4 production by NKT cells. J Immunol 179: $111-119$.
Au-Yeung BB, Katzman SD, Fowell DJ. 2006. Cutting edge: Itk-dependent signals required for CD4+ T cells to exert, but not gain, Th2 effector function. J Immunol 176: 3895-3899.

August A. 2009. IL-2-inducible T-cell kinase (ITK) finds another (dance) partner ... TFII-I. Eur J Immunol 39: 2354-2357.

August A, Sadra A, Dupont B, Hanafusa H. 1997. Srcinduced activation of inducible $\mathrm{T}$ cell kinase (ITK) requires phosphatidylinositol 3-kinase activity and the Pleckstrin homology domain of inducible $\mathrm{T}$ cell kinase. Proc Natl Acad Sci U S A 94: 11227-11232.

Azuara V, Levraud JP, Lembezat MP, Pereira P. 1997. A novel subset of adult gamma delta thymocytes that secretes a distinct pattern of cytokines and expresses a very restricted T cell receptor repertoire. Eur J Immunol 27: 544-553.

Bachmann MF, Littman DR, Liao XC. 1997. Antiviral immune responses in Itk-deficient mice. J Virol 71 $7253-7257$.

Baker JE, Majeti R, Tangye SG, Weiss A. 2001. Protein tyrosine phosphatase CD148-mediated inhibition of T-cel receptor signal transduction is associated with reduced LAT and phospholipase Cgammal phosphorylation. Mol Cell Biol 21: 2393-2403.

Beach D, Gonen R, Bogin Y, Reischl IG, Yablonski D. 2007. Dual role of SLP-76 in mediating T cell receptor-induced activation of phospholipase C-gammal. J Biol Chem 282: 2937-2946.

Bendelac A. 1995. Positive selection of mouse NK1+ T cells by CD1-expressing cortical thymocytes. J Exp Med 182: 2091-2096.

Berg LJ. 2007. Signalling through TEC kinases regulates conventional versus innate CD8(+) T-cell development. Nat Rev Immunol 7: 479-485.

Berg LJ. 2009. Strength of T cell receptor signaling strikes again. Immunity 31: 529-531.

Berg LJ, Finkelstein LD, Lucas JA, Schwartzberg PL. 2005. Tec family kinases in T lymphocyte development and function. Annu Rev Immunol 23: 549-600.

Blomberg KE, Boucheron N, Lindvall JM, Yu L, Raberger J, Berglof A, Ellmeier W, Smith CE. 2009. Transcriptional signatures of Itk-deficient $\mathrm{CD} 3+, \mathrm{CD} 4+$ and $\mathrm{CD} 8+$ T-cells. BMC Genomics 10: 233.

Bogin Y, Ainey C, Beach D, Yablonski D. 2007. SLP-76 mediates and maintains activation of the Tec family kinase ITK via the $\mathrm{T}$ cell antigen receptor-induced association between SLP-76 and ITK. Proc Natl Acad Sci U S A 104: 6638-6643.

Bosselut R. 2004. CD4/CD8-lineage differentiation in the thymus: from nuclear effectors to membrane signals. Nat Rev Immunol 4: 529-540.

Braiman A, Barda-Saad M, Sommers CL, Samelson LE. 2006. Recruitment and activation of PLCgammal in T cells: a new insight into old domains. EMBO $J$ 25: 774-784.

Brazin KN, Fulton DB, Andreotti AH. 2000. A specific intermolecular association between the regulatory domains of a Tec family kinase. J Mol Biol 302: 607-623.

Brazin KN, Mallis RJ, Fulton DB, Andreotti AH. 2002. Regulation of the tyrosine kinase Itk by the peptidyl-prolyl 
isomerase cyclophilin A. Proc Natl Acad Sci U S A 99: 1899-1904.

Broussard C, Fleischacker C, Horai R, Chetana M, Venegas AM, Sharp LL, Hedrick SM, Fowlkes BJ, Schwartzberg PL. 2006. Altered development of CD8 + T cell lineages in mice deficient for the Tec kinases Itk and Rlk. Immunity 25: 93-104.

Brown MT, Cooper JA. 1996. Regulation, substrates and functions of src. Biochim Biophys Acta 1287: 121-149.

Bubeck Wardenburg J, Fu C, Jackman JK, Flotow H, Wilkinson SE, Williams DH, Johnson R, Kong G, Chan AC, Findell PR. 1996. Phosphorylation of SLP-76 by the ZAP-70 protein-tyrosine kinase is required for T-cell receptor function. J Biol Chem 271: 19641-19644.

Bunnell SC, Diehn M, Yaffe MB, Findell PR, Cantley LC, Berg LJ. 2000. Biochemical interactions integrating Itk with the $\mathrm{T}$ cell receptor-initiated signaling cascade. J Biol Chem 275: 2219-2230.

Bunnell SC, Singer AL, Hong DI, Jacque BH, Jordan MS, Seminario MC, Barr VA, Koretzky GA, Samelson LE. 2006. Persistence of cooperatively stabilized signaling clusters drives T-cell activation. Mol Cell Biol 26: 7155-7166.

Chamorro M, Czar MJ, Debnath J, Cheng G, Lenardo MJ, Varmus HE, Schwartzberg PL. 2001. Requirements for activation and RAFT localization of the T-lymphocyte kinase Rlk/Txk. BMC Immunol 2: 3.

Ching KA, Grasis JA, Tailor P, Kawakami Y, Kawakami T, Tsoukas CD. 2000. TCR/CD3-Induced activation and binding of Emt/Itk to linker of activated T cell complexes: requirement for the Src homology 2 domain. J Immunol 165: 256-262.

Ching KA, Kawakami Y, Kawakami T, Tsoukas CD. 1999. Emt/Itk associates with activated TCR complexes: role of the pleckstrin homology domain. J Immunol 163: 6006-6013.

Ciofani M, Zuniga-Pflucker JC. 2006. A survival guide to early T cell development. Immunol Res 34: 117-132.

Colgan J, Asmal M, Neagu M, Yu B, Schneidkraut J, Lee Y, Sokolskaja E, Andreotti A, Luban J. 2004. Cyclophilin A regulates TCR signal strength in CD4 $+\mathrm{T}$ cells via a proline-directed conformational switch in Itk. Immunity 21: 189-201.

Cowan-Jacob SW, Fendrich G, Manley PW, Jahnke W, Fabbro D, Liebetanz J, Meyer T. 2005. The crystal structure of a c-Src complex in an active conformation suggests possible steps in c-Src activation. Structure 13: 861-871.

Crabtree GR, Olson EN. 2002. NFAT signaling: choreographing the social lives of cells. Cell 109 Suppl: S67-79.

Cruz-Orcutt N, Houtman JC. 2009. PI3 kinase function is vital for the function but not formation of LAT-mediated signaling complexes. Mol Immunol 46: 2274-2283.

Dombroski D, Houghtling RA, Labno CM, Precht P, Takesono A, Caplen NJ, Billadeau DD, Wange RL, Burkhardt JK, Schwartzberg PL. 2005. Kinase-independent functions for Itk in TCR-induced regulation of Vav and the actin cytoskeleton. J Immunol 174: 1385-1392.

Dubois S, Waldmann TA, Muller JR. 2006. ITK and IL-15 support two distinct subsets of CD8+ T cells. Proc Natl Acad Sci U S A 103: 12075-12080.
Felices M, Berg LJ. 2008. The Tec kinases Itk and Rlk regulate NKT cell maturation, cytokine production, and survival. J Immunol 180: 3007-3018.

Felices M, Falk M, Kosaka Y, Berg LJ. 2007. Tec kinases in T cell and mast cell signaling. Adv Immunol 93: 145-184.

Felices M, Yin CC, Kosaka Y, Kang J, Berg LJ. 2009. Tec kinase Itk in $\gamma \delta \mathrm{T}$ cells is pivotal for controlling IgE production in vivo. Proc Natl Acad Sci 106: 8308-8313.

Fischer AM, Mercer JC, Iyer A, Ragin MJ, August A. 2004. Regulation of CXC chemokine receptor 4-mediated migration by the Tec family tyrosine kinase ITK. J Biol Chem 279: 29816-29820.

Fowell DJ, Shinkai K, Liao XC, Beebe AM, Coffman RL, Littman DR, Locksley RM. 1999. Impaired NFATc translocation and failure of Th2 development in Itk-deficient CD4+ T cells. Immunity 11: 399-409.

Fukuda M, Kojima T, Kabayama H, Mikoshiba K. 1996. Mutation of the pleckstrin homology domain of Bruton's tyrosine kinase in immunodeficiency impaired inositol 1,3,4,5-tetrakisphosphate binding capacity. J Biol Chem 271: 30303-30306.

Gadue P, Stein PL. 2002. NK T cell precursors exhibit differential cytokine regulation and require Itk for efficient maturation. J Immunol 169: 2397-2406.

Garcon F, Nunes JA. 2006. Travel informations on the Tec kinases during lymphocyte activation. Adv Exp Med Biol 584: 15-27.

Gibson S, Leung B, Squire JA, Hill M, Arima N, Goss P, Hogg D, Mills GB. 1993. Identification, cloning, and characterization of a novel human T-cell-specific tyrosine kinase located at the hematopoietin complex on chromosome 5q. Blood 82: 1561-1572.

Gilfillan AM, Rivera J. 2009. The tyrosine kinase network regulating mast cell activation. Immunol Rev 228: $149-169$.

Gomez-Rodriguez J, Readinger JA, Viorritto IC, Mueller KL, Houghtling RA, Schwartzberg PL. 2007. Tec kinases, actin, and cell adhesion. Immunol Rev 218: 45-64.

Gomez-Rodriguez J, Sahu N, Handon R, Davidson TS, Anderson SM, Kirby MR, August A, Schwartzberg PL. 2009. Differential expression of interleukin-17A and $-17 \mathrm{~F}$ is coupled to $\mathrm{T}$ cell receptor signaling via inducible T cell kinase. Immunity 31: 587-597.

Graef IA, Holsinger LJ, Diver S, Schreiber SL, Crabtree GR. 1997. Proximity and orientation underlie signaling by the non-receptor tyrosine kinase ZAP70. EMBO J 16: $5618-5628$.

Graves PE, Siroux V, Guerra S, Klimecki WT, Martinez FD. 2005. Association of atopy and eczema with polymorphisms in T-cell immunoglobulin domain and mucin domain-IL-2-inducible T-cell kinase gene cluster in chromosome 5 q 33. J Allergy Clin Immunol 116: 650-656.

Guo S, Wahl MI, Witte ON. 2006. Mutational analysis of the SH2-kinase linker region of Bruton's tyrosine kinase defines alternative modes of regulation for cytoplasmic tyrosine kinase families. Int Immunol 18: 79-87.

Hansson H, Okoh MP, Smith CI, Vihinen M, Hard T. 2001. Intermolecular interactions between the $\mathrm{SH} 3$ domain and the proline-rich TH region of Bruton's tyrosine kinase. FEBS Lett 489: 67-70. 
A.H. Andreotti et al.

Hao S, August A. 2002. The proline rich region of the Tec homology domain of ITK regulates its activity. FEBS Lett 525: 53-58.

Hao S, Qi Q, Hu J, August A. 2006. A kinase independent function for Tec kinase ITK in regulating antigen receptor induced serum response factor activation. FEBS Lett 580: 2691-2697.

Hawkins J, Marcy A. 2001. Characterization of Itk tyrosine kinase: contribution of noncatalytic domains to enzymatic activity. Protein Expr Purif 22: 211-219.

Heyeck SD, Berg LJ. 1993. Developmental regulation of a murine T-cell-specific tyrosine kinase gene, Tsk. Proc Natl Acad Sci U S A 90: 669-673.

Heyeck SD, Wilcox HM, Bunnell SC, Berg LJ. 1997. Lck phosphorylates the activation loop tyrosine of the Itk kinase domain and activates Itk kinase activity. $J$ Biol Chem 272: 25401-25408.

Horai R, Mueller KL, Handon RA, Cannons JL, Anderson SM, Kirby MR, Schwartzberg PL. 2007. Requirements for selection of conventional and innate T lymphocyte lineages. Immunity 27: 775-785.

Houtman JC, Houghtling RA, Barda-Saad M, Toda Y, Samelson LE. 2005. Early phosphorylation kinetics of proteins involved in proximal TCR-mediated signaling pathways. J Immunol 175: 2449-2458.

Houtman JC, Yamaguchi H, Barda-Saad M, Braiman A, Bowden B, Appella E, Schuck P, Samelson LE. 2006. Oligomerization of signaling complexes by the multipoint binding of GRB2 to both LAT and SOS1. Nat Struct Mol Biol 13: 798-805.

Hu J, August A. 2008. Naive and innate memory phenotype $\mathrm{CD} 4+\mathrm{T}$ cells have different requirements for active Itk for their development. J Immunol 180: 6544-6552.

Hu J, Sahu N, Walsh E, August A. 2007. Memory phenotype $\mathrm{CD} 8+\mathrm{T}$ cells with innate function selectively develop in the absence of active Itk. Eur J Immunol 37: 2892-2899.

Huang K, Wang YH, Brown A, Sun G. 2009. Identification of N-terminal lobe motifs that determine the kinase activity of the catalytic domains and regulatory strategies of Src and Csk protein tyrosine kinases. J Mol Biol 386: 1066-1077.

Huang YH, Grasis JA, Miller AT, Xu R, Soonthornvacharin S, Andreotti AH, Tsoukas CD, Cooke MP, Sauer K. 2007. Positive regulation of Itk $\mathrm{PH}$ domain function by soluble IP4. Science 316: 886-889.

Huck K, Feyen O, Niehues T, Ruschendorf F, Hubner N, Laws HJ, Telieps T, Knapp S, Wacker HH, Meindl A, et al. 2009. Girls homozygous for an IL-2-inducible T cell kinase mutation that leads to protein deficiency develop fatal EBV-associated lymphoproliferation. J Clin Invest 119: 1350-1358.

Huse M, Eck MJ, Harrison SC. 1998. A Zn2+ ion links the cytoplasmic tail of CD4 and the $\mathrm{N}$-terminal region of Lck. J Biol Chem 273: 18729-18733.

Hwang ES, Szabo SJ, Schwartzberg PL, Glimcher LH. 2005. Thelper cell fate specified by kinase-mediated interaction of T-bet with GATA-3. Science 307: 430-433.

Ishigame H, Kakuta S, Nagai T, Kadoki M, Nambu A, Komiyama Y, Fujikado N, Tanahashi Y, Akitsu A, Kotaki $\mathrm{H}$, et al. 2009. Differential roles of interleukin-17A and
$-17 \mathrm{~F}$ in host defense against mucoepithelial bacterial infection and allergic responses. Immunity 30: 108-119.

Jameson SC, Hogquist KA, Bevan MJ. 1995. Positive selection of thymocytes. Annu Rev Immunol 13: 93-126.

Jordan MS, Smith JE, Burns JC, Austin JE, Nichols KE, Aschenbrenner AC, Koretzky GA. 2008. Complementation in trans of altered thymocyte development in mice expressing mutant forms of the adaptor molecule SLP76. Immunity 28: 359-369.

Joseph RE, Andreotti AH. 2009. Conformational snapshots of Tec kinases during signaling. Immunol Rev 228: 74-92.

Joseph RE, Fulton DB, Andreotti AH. 2007a. Mechanism and functional significance of Itk autophosphorylation. J Mol Biol 373: 1281-1292.

Joseph RE, Min L, Andreotti AH. 2007b. The linker between $\mathrm{SH} 2$ and kinase domains positively regulates catalysis of the Tec family kinases. Biochemistry 46: 5455-5462.

Joseph RE, Min L, Xu R, Musselman ED, Andreotti AH. 2007c. A remote substrate docking mechanism for the tec family tyrosine kinases. Biochemistry 46: 5595-5603.

Koprulu AD, Ellmeier W. 2009. The role of Tec family kinases in mononuclear phagocytes. Crit Rev Immunol 29: 317-333.

Koretzky GA, Abtahian F, Silverman MA. 2006. SLP76 and SLP65: complex regulation of signalling in lymphocytes and beyond. Nat Rev Immunol 6: 67-78.

Korn T, Bettelli E, Oukka M, Kuchroo VK. 2009. IL-17 and Th17 Cells. Annu Rev Immunol 27: 485-517.

Kreslavsky T, Savage AK, Hobbs R, Gounari F, Bronson R, Pereira P, Pandolfi PP, Bendelac A, von Boehmer H 2009. TCR-inducible PLZF transcription factor required for innate phenotype of a subset of gammadelta T cells with restricted TCR diversity. Proc Natl Acad Sci U S A 106: $12453-12458$.

Labno CM, Lewis CM, You D, Leung DW, Takesono A, Kamberos N, Seth A, Finkelstein LD, Rosen MK, Schwartzberg PL, et al. 2003. Itk functions to control actin polymerization at the immune synapse through localized activation of Cdc42 and WASP. Curr Biol 13: 1619-1624.

Laederach A, Cradic KW, Brazin KN, Zamoon J, Fulton DB, Huang XY, Andreotti AH. 2002. Competing modes of self-association in the regulatory domains of Bruton's tyrosine kinase: intramolecular contact versus asymmetric homodimerization. Protein Sci 11: 36-45.

Laederach A, Cradic KW, Fulton DB, Andreotti AH. 2003. Determinants of intra versus intermolecular selfassociation within the regulatory domains of Rlk and Itk. J Mol Biol 329: 1011-1020.

LaFevre-Bernt M, Sicheri F, Pico A, Porter M, Kuriyan J, Miller WT. 1998. Intramolecular regulatory interactions in the Src family kinase Hck probed by mutagenesis of a conserved tryptophan residue. J Biol Chem 273: 32129-32134.

Lees RK, Ferrero I, MacDonald HR. 2001. Tissue-specific segregation of TCRgamma delta + NKT cells according to phenotype TCR repertoire and activation status: parallels with TCR alphabeta+NKT cells. Eur J Immunol 31: 2901-2909.

Lewis RS, Cahalan MD. 1995. Potassium and calcium channels in lymphocytes. Annu Rev Immunol 13: 623-653. 
Liao XC, Littman DR. 1995. Altered T cell receptor signaling and disrupted $\mathrm{T}$ cell development in mice lacking Itk. Immunity 3: 757-769.

Lin L, Czerwinski R, Kelleher K, Siegel MM, Wu P, Kriz R, Aulabaugh A, Stahl M. 2009. Activation loop phosphorylation modulates Bruton's tyrosine kinase (Btk) kinase domain activity. Biochemistry 48: 2021-2032.

Lin X, Ayrapetov MK, Lee S, Parang K, Sun G. 2005. Probing the communication between the regulatory and catalytic domains of a protein tyrosine kinase, Csk. Biochemistry 44: 1561-1567.

Liu KQ, Bunnell SC, Gurniak CB, Berg LJ. 1998. T cell receptor-initiated calcium release is uncoupled from capacitative calcium entry in Itk-deficient T cells. J Exp Med 187: 1721-1727.

Lucas JA, Atherly LO, Berg LJ. 2002. The absence of Itk inhibits positive selection without changing lineage commitment. J Immunol 168: 6142-6151.

Lucas JA, Felices M, Evans JW, Berg LJ. 2007. Subtle defects in pre-TCR signaling in the absence of the Tec kinase Itk. J Immunol 179: 7561-7567.

Lucas JA, Miller AT, Atherly LO, Berg LJ. 2003. The role of Tec family kinases in T cell development and function. Immunol Rev 191: 119-138.

Marcotte DJ, Liu YT, Arduini RM, Hession CA, Miatkowski K, Wildes CP, Cullen PF, Hong V, Hopkins BT, Mertsching E, et al. 2010. Structures of human Bruton's tyrosine kinase in active and inactive conformations suggest a mechanism of activation for TEC family kinases. Protein Sci 19: 429-439.

Marquez JA, Smith CI, Petoukhov MV, Lo Surdo P, Mattsson PT, Knekt M, Westlund A, Scheffzek K, Saraste M Svergun DI. 2003. Conformation of full-length Bruton tyrosine kinase (Btk) from synchrotron X-ray solution scattering. $Е M B O J$ 22: 4616-4624.

Mihara S, Suzuki N. 2007. Role of Txk, a member of the Tec family of tyrosine kinases, in immune-inflammatory diseases. Int Rev Immunol 26: 333-348.

Miller AT, Berg LJ. 2002. Defective Fas ligand expression and activation-induced cell death in the absence of IL-2-inducible T cell kinase. J Immunol 168: 2163-2172.

Miller AT, Wilcox HM, Lai Z, Berg LJ. 2004. Signaling through Itk promotes $T$ helper 2 differentiation via negative regulation of T-bet. Immunity 21: 67-80.

Min L, Joseph RE, Fulton DB, Andreotti AH. 2009. Itk tyrosine kinase substrate docking is mediated by a nonclassical SH2 domain surface of PLCgamma1. Proc Natl Acad Sci U S A 106: 21143-21148.

Min L, Wu W, Joseph RE, Fulton DB, Berg L, Andreotti AH. 2010. Disrupting the intermolecular self-association of Itk enhances $\mathrm{T}$ cell signaling. J Immunology 184: $4228-4235$.

Mohamed AJ, Yu L, Backesjo CM, Vargas L, Faryal R, Aints A, Christensson B, Berglof A, Vihinen M, Nore BF, et al. 2009. Bruton's tyrosine kinase (Btk): function, regulation, and transformation with special emphasis on the PH domain. Immunol Rev 228: 58-73.

Mueller C, August A. 2003. Attenuation of Immunological Symptoms of Allergic Asthma in Mice Lacking the Tyrosine Kinase ITK. J Immunol 170: 5056-5063.
Neal JW, Clipstone NA. 2003. A constitutively active NFATc1 mutant induces a transformed phenotype in 3T3-L1 fibroblasts. J Biol Chem 278: 17246-17254.

Nunez-Cruz S, Aguado E, Richelme S, Chetaille B, Mura AM, Richelme M, Pouyet L, Jouvin-Marche E, Xerri L, Malissen B, et al. 2003. LAT regulates gammadelta T cell homeostasis and differentiation. Nat Immunol 4: 9991008.

Nurieva RI, Chuvpilo S, Wieder ED, Elkon KB, Locksley R, Serfling E, Dong C. 2007. A costimulation-initiated signaling pathway regulates NFATcl transcription in T lymphocytes. J Immunol 179: 1096-1103.

Okoh MP, Vihinen M. 2002. Interaction between Btk TH and SH3 domain. Biopolymers 63: 325-334.

Palacios EH, Weiss A. 2004. Function of the Src-family kinases, Lck and Fyn, in T-cell development and activation. Oncogene 23: 7990-8000.

Pawson T, Kofler M. 2009. Kinome signaling through regulated protein-protein interactions in normal and cancer cells. Curr Opin Cell Biol 21: 147-153.

Perez-Villar JJ, Kanner SB. 1999. Regulated association between the tyrosine kinase Emt/Itk/Tsk and phospholipase-C gamma 1 in human T lymphocytes. J Immunol 163: 6435-6441.

Pitcher LA, van Oers NS. 2003. T-cell receptor signal transmission: who gives an ITAM? Trends Immunol 24: $554-560$.

Pletneva EV, Sundd M, Fulton DB, Andreotti AH. 2006. Molecular details of Itk activation by prolyl isomerization and phospholigand binding: the NMR structure of the Itk SH2 domain bound to a phosphopeptide. J Mol Biol 357: $550-561$.

Prince AL, Yin CC, Enos ME, Felices M, Berg LJ. 2009. The Tec kinases Itk and Rlk regulate conventional versus innate T-cell development. Immunol Rev 228: $115-131$.

Punt JA, Osborne BA, Takahama Y, Sharrow SO, Singer A. 1994. Negative selection of CD4+CD8+ thymocytes by $\mathrm{T}$ cell receptor-induced apoptosis requires a costimulatory signal that can be provided by CD28. J Exp Med 179: 709-713.

Pursglove SE, Mulhern TD, Mackay JP, Hinds MG, Booker GW. 2002. The solution structure and intramolecular associations of the Tec kinase SRC homology 3 domain. J Biol Chem 277: 755-762.

Qi Q, August A. 2009. The tec family kinase itk exists as a folded monomer in vivo. J Biol Chem 284: 29882-29892.

Qi Q, Sahu N, August A. 2006. Tec kinase Itk forms membrane clusters specifically in the vicinity of recruiting receptors. J Biol Chem 281: 38529-38534.

Qi Q, Xia M, Hu J, Hicks E, Iyer A, Xiong N, August A. 2009. Enhanced development of CD4+ gammadelta T cells in the absence of Itk results in elevated IgE production. Blood 114: 564-571.

Raberger J, Schebesta A, Sakaguchi S, Boucheron N, Blomberg KE, Berglof A, Kolbe T, Smith CI, Rulicke T, Ellmeier W. 2008. The transcriptional regulator PLZF induces the development of CD44 high memory phenotype T cells. Proc Natl Acad Sci U S A 105: 17919-17924.

Rawlings DJ, Saffran DC, Tsukada S, Largaespada DA, Grimaldi JC, Cohen L, Mohr RN, Bazan JF, Howard M, 
A.H. Andreotti et al.

Copeland NG, et al. 1993. Mutation of unique region of Bruton's tyrosine kinase in immunodeficient XID mice. Science 261: 358-361.

Readinger JA, Mueller KL, Venegas AM, Horai R, Schwartzberg PL. 2009. Tec kinases regulate T-lymphocyte development and function: new insights into the roles of Itk and Rlk/Txk. Immunol Rev 228: 93-114.

Rhee SG. 2001. Regulation of phosphoinositide-specific phospholipase C. Annu Rev Biochem 70: 281-312.

Sacristan C, Schattgen SA, Berg LJ, Bunnell SC, Roy AL, Rosenstein Y. 2009. Characterization of a novel interaction between transcription factor TFII-I and the inducible tyrosine kinase in T cells. Eur J Immunol 39: 2584-2595.

Sahu N, Mueller C, Fischer A, August A. 2008a. Differential sensitivity to Itk kinase signals for T helper 2 cytokine production and chemokine-mediated migration. $J$ Immunol 180: 3833-3838.

Sahu N, Venegas AM, Jankovic D, Mitzner W, GomezRodriguez J, Cannons JL, Sommers C, Love P, Sher A, Schwartzberg PL, et al. 2008b. Selective expression rather than specific function of Txk and Itk regulate Th1 and Th2 responses. J Immunol 181: 6125-6131.

Schaeffer EM, Broussard C, Debnath J, Anderson S, McVicar DW, Schwartzberg PL. 2000. Tec family kinases modulate thresholds for thymocyte development and selection. J Exp Med 192: 987-1000.

Schaeffer EM, Debnath J, Yap G, McVicar D, Liao XC, Littman DR, Sher A, Varmus HE, Lenardo MJ, Schwartzberg PL. 1999. Requirement for Tec kinases Rlk and Itk in T cell receptor signaling and immunity. Science 284: $638-641$.

Schaeffer EM, Yap GS, Lewis CM, Czar MJ, McVicar DW, Cheever AW, Sher A, Schwartzberg PL. 2001. Mutation of Tec family kinases alters $\mathrm{T}$ helper cell differentiation. Nat Immunol 2: 1183-1188.

Seminario MC, Bunnell SC. 2008. Signal initiation in T-cell receptor microclusters. Immunol Rev 221: 90-106.

Severin A, Joseph RE, Boyken S, Fulton DB, Andreotti AH. 2009. Proline isomerization preorganizes the Itk SH2 domain for binding to the Itk SH3 domain. J Mol Biol 387: $726-743$.

Shan X, Czar MJ, Bunnell SC, Liu P, Liu Y, Schwartzberg PL, Wange RL. 2000. Deficiency of PTEN in Jurkat T cells causes constitutive localization of Itk to the plasma membrane and hyperresponsiveness to $\mathrm{CD} 3$ stimulation. Mol Cell Biol 20: 6945-6957.

Shan X, Wange RL. 1999. Itk/Emt/Tsk activation in response to $\mathrm{CD} 3$ cross-linking in Jurkat $\mathrm{T}$ cells requires ZAP-70 and Lat and is independent of membrane recruitment. J Biol Chem 274: 29323-29330.

Siliciano JD, Morrow TA, Desiderio SV. 1992. itk, a T-cell-specific tyrosine kinase gene inducible by interleukin 2. Proc Natl Acad Sci U S A 89: 11194-11198.

Smith-Garvin JE, Koretzky GA, Jordan MS. 2009. T cell activation. Annu Rev Immunol 27: 591-619.

Sommers CL, Rabin RL, Grinberg A, Tsay HC, Farber J, Love PE. 1999. A role for the Tec family tyrosine kinase Txk in T cell activation and thymocyte selection. J Exp Med 190: 1427-1438.
Sommers CL, Samelson LE, Love PE. 2004. LAT: a $\mathrm{T}$ lymphocyte adapter protein that couples the antigen receptor to downstream signaling pathways. Bioessays 26: 61-67.

Streubel B, Vinatzer U, Willheim M, Raderer M, Chott A. 2006. Novel $t(5 ; 9)(q 33 ; q 22)$ fuses ITK to SYK in unspecified peripheral T-cell lymphoma. Leukemia 20: 313-318.

Su YW, Zhang Y, Schweikert J, Koretzky GA, Reth M, Wienands J. 1999. Interaction of SLP adaptors with the $\mathrm{SH} 2$ domain of Tec family kinases. Eur J Immunol 29: 3702-3711.

Takesono A, Horai R, Mandai M, Dombroski D, Schwartzberg PL. 2004. Requirement for Tec kinases in chemokine-induced migration and activation of $\mathrm{Cdc} 42$ and Rac. Curr Biol 14: 917-922.

Tanaka N, Asao H, Ohtani K, Nakamura M, Sugamura K. 1993. A novel human tyrosine kinase gene inducible in T cells by interleukin 2. FEBS Lett 324: 1-5.

Thomas JD, Sideras P, Smith CI, Vorechovsky I, Chapman V, Paul WE. 1993. Colocalization of X-linked agammaglobulinemia and $\mathrm{X}$-linked immunodeficiency genes. Science 261: 355-358.

Tomlinson MG, Heath VL, Turck CW, Watson SP, Weiss A. 2004. SHIP family inositol phosphatases interact with and negatively regulate the Tec tyrosine kinase. J Biol Chem 279: 55089-55096.

Tsukada S, Saffran DC, Rawlings DJ, Parolini O, Allen RC, Klisak I, Sparkes RS, Kubagawa H, Mohandas T, Quan S, et al. 1993. Deficient expression of a B cell cytoplasmic tyrosine kinase in human X-linked agammaglobulinemia. Cell 72: 279-290.

Tsygankov AY. 2003. Non-receptor protein tyrosine kinases. Front Biosci 8: 595-635.

van de Weyer PS, Muehlfeit M, Klose C, Bonventre JV, Walz G, Kuehn EW. 2006. A highly conserved tyrosine of Tim-3 is phosphorylated upon stimulation by its ligand galectin-9. Biochem Biophys Res Commun 351: 571-576.

Vetrie D, Vorechovsky I, Sideras P, Holland J, Davies A, Flinter F, Hammarstrom L, Kinnon C, Levinsky R, Bobrow M, et al. 1993. The gene involved in X-linked agammaglobulinaemia is a member of the src family of protein-tyrosine kinases. Nature 361: 226-233.

Vicari AP, Mocci S, Openshaw P, O'Garra A, Zlotnik A. 1996. Mouse gamma delta TCR + NK1.1+ thymocytes specifically produce interleukin-4, are major histocompatibility complex class I independent, and are developmentally related to alpha beta TCR + NK1.1+ thymocytes. Eur J Immunol 26: 1424-1429.

Wilcox HM, Berg LJ. 2003. Itk phosphorylation sites are required for functional activity in primary T cells. J Biol Chem 278: 37112-37121.

Williams JC, Wierenga RK, Saraste M. 1998. Insights into Src kinase functions: structural comparisons. Trends Biochem Sci 23: 179-184.

Wilson CB, Rowell E, Sekimata M. 2009. Epigenetic control of T-helper-cell differentiation. Nat Rev Immunol 9: 91-105. 
Tec Kinase Itk in T-Cell Signaling

Winslow MM, Neilson JR, Crabtree GR. 2003. Calcium signalling in lymphocytes. Curr Opin Immunol 15:299-307.

Xu W, Doshi A, Lei M, Eck MJ, Harrison SC. 1999. Crysta structures of c-Src reveal features of its autoinhibitory mechanism. Mol Cell 3: 629-638.

Xu W, Harrison SC, Eck MJ. 1997. Three-dimensional structure of the tyrosine kinase c-Src. Nature 385: 595-602.

Yamada N, Kawakami Y, Kimura H, Fukamachi H, Baier G, Altman A, Kato T, Inagaki Y, Kawakami T. 1993. Structure and expression of novel protein-tyrosine kinases, Emb and Emt, in hematopoietic cells. Biochem Biophys Res Commun 192: 231-240.

Yang W, Malek SN, Desiderio S. 1995. An SH3-binding site conserved in Bruton's tyrosine kinase and related tyrosine kinases mediates specific protein interactions in vitro and in vivo. J Biol Chem 270: 20832-20840.
Yang WC, Ching KA, Tsoukas CD, Berg LJ. 2001. Tec kinase signaling in $\mathrm{T}$ cells is regulated by phosphatidylinositol 3-kinase and the Tec pleckstrin homology domain. J Immunol 166: 387-395.

Yang XO, Chang SH, Park H, Nurieva R, Shah B, Acero L, Wang YH, Schluns KS, Broaddus RR, Zhu Z, et al. 2008. Regulation of inflammatory responses by IL-17F. J Exp Med 205: 1063-1075.

Yu L, Mohamed AJ, Vargas L, Berglof A, Finn G, Lu KP, Smith CI. 2006. Regulation of Bruton tyrosine kinase by the peptidylprolyl isomerase Pin1. J Biol Chem 281 18201-18207.

Zhang W, Sloan-Lancaster J, Kitchen J, Trible RP, Samelson LE. 1998. LAT: the ZAP-70 tyrosine kinase substrate that links $\mathrm{T}$ cell receptor to cellular activation. Cell $\mathbf{9 2}$ : 83-92. 


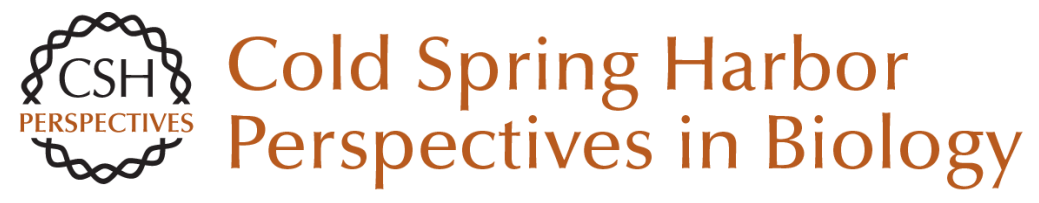

\section{T-Cell Signaling Regulated by the Tec Family Kinase, Itk}

Amy H. Andreotti, Pamela L. Schwartzberg, Raji E. Joseph and Leslie J. Berg

Cold Spring Harb Perspect Biol 2010; doi: 10.1101/cshperspect.a002287 originally published online June 2, 2010

\section{Subject Collection Immunoreceptor Signaling}

The Coordination of T-cell Function by Serine/Threonine Kinases

David Finlay and Doreen Cantrell

ITAM-mediated Signaling by the T-Cell Antigen Receptor

Paul E. Love and Sandra M. Hayes

Coordination of Receptor Signaling in Multiple Hematopoietic Cell Lineages by the Adaptor

Protein SLP-76

Martha S. Jordan and Gary A. Koretzky

The Cytoskeleton Coordinates the Early Events of B-cell Activation

Naomi E. Harwood and Facundo D. Batista

An Enigmatic Tail of CD28 Signaling

Jonathan S. Boomer and Jonathan M. Green

\section{Mediation of T-Cell Activation by Actin Meshworks \\ Peter Beemiller and Matthew F. Krummel}

T-Cell Signaling Regulated by the Tec Family

Kinase, Itk

Amy H. Andreotti, Pamela L. Schwartzberg, Raji E. Joseph, et al.
Perspectives for Computer Modeling in the Study of T Cell Activation Jesse Coward, Ronald N. Germain and Grégoire Altan-Bonnet

Structural Biology of the T-cell Receptor: Insights into Receptor Assembly, Ligand Recognition, and Initiation of Signaling

Kai W. Wucherpfennig, Etienne Gagnon, Melissa J. Call, et al.

Src-family and Syk Kinases in Activating and Inhibitory Pathways in Innate Immune Cells:

Signaling Cross Talk Clifford A. Lowell

The LAT Story: A Tale of Cooperativity, Coordination, and Choreography

Lakshmi Balagopalan, Nathan P. Coussens, Eilon Sherman, et al.

Antigen Receptor Signaling to NF- $\mathrm{KB}$ via CARMA1, BCL10, and MALT1 Margot Thome, Jean Enno Charton, Christiane Pelzer, et al.

It's All About Change: The Antigen-driven Initiation of B-Cell Receptor Signaling Wanli Liu, Hae Won Sohn, Pavel Tolar, et al.

ZAP-70: An Essential Kinase in T-cell Signaling Haopeng Wang, Theresa A. Kadlecek, Byron B. Au-Yeung, et al.

For additional articles in this collection, see http://cshperspectives.cshlp.org/cgi/collection/

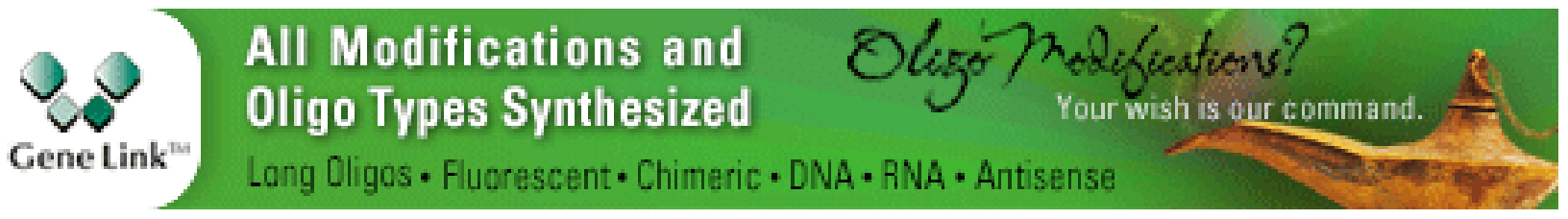




\section{Lipid Signaling in T-Cell Development and Function \\ Yina H. Huang and Karsten Sauer}

Understanding the Structure and Function of the Immunological Synapse

Michael L. Dustin, Arup K. Chakraborty and Andrey S. Shaw

For additional articles in this collection, see http://cshperspectives.cshlp.org/cgi/collection/

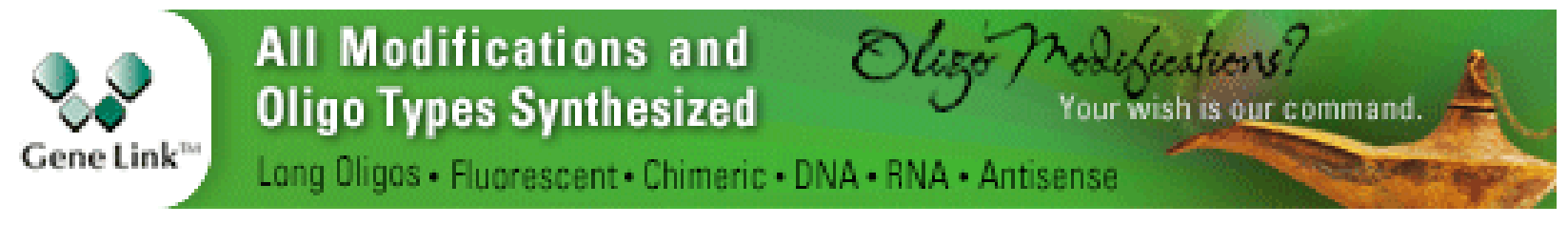

Copyright @ 2010 Cold Spring Harbor Laboratory Press; all rights reserved 